\title{
Nano-Porous Silicon-Based Mini Hydrogen Fuel Cells
}

\author{
Tayyar Dzhafarov ${ }^{1}$ and Sureyya Aydin Yuksel ${ }^{2}$ \\ ${ }^{1}$ Institute of Physics, Azerbaijan National Academy of Sciences, Baku \\ 2Department of Physics, Yildiz Technical University, 34210 Esenler/Istanbul \\ ${ }^{1}$ Azerbaijan \\ 2Turkey
}

\section{Introduction}

Hydrogen is an important chemical material that is utilized in a large scale in synthetic chemical industries in modern society. On the other hand, technologies for utilizing hydrogen as clean source of energy are considered to assume an important position in order to overcome problems of lack of energy and environment in future. Hence, fuel cells that store hydrogen and operate using it as fuel are developed (Hoffmann, 2002). Such fuel cell is a battery which is actuated by gas. Energy obtained upon a reaction of hydrogen and oxygen is directly converted into electric energy. Fuel cells offer a significant advantage over traditional combusting-based thermal energy conversion, so they provide efficiencies of electrical power supply in the range of 35 to 55\%, causing very low level of pollutant emission. They can be used in a wide variety of applications from miniaturized portable power to stationary power stations (Mench, 2008; O'Hayre et al., 2009; Vialstich et al., 2003). Nowadays the rise in portable electronics requires energy sources compatible with the environmental constrains. Portable fuel cells are expected to come first and open the market for other applications. The potential of portable fuel cells includes portable electronics devices (portable computers, cameras, electronic games, phones, audio players, televisions etc.), weather stations, signal units, medical devices etc. Proton exchange membrane (PEM)type fuel cell is attractive and alternative option for production of clean energy for portable and transportation applications (Hockaday, 2000; Hahn et al., 2007). It consists of an organic polymer membrane as proton conductor (Nafion $\left.{ }^{\circledR}\right)$ sandwiched between two the platinumbased catalysts. Fuel cell operates under clear hydrogen exposition at $100-300 \circ \mathrm{C}$. An external reformer is required to convert fuel such as methanol or natural gas to hydrogen. However, the major hurdles for commercialization of system with PEM fuel cell consist of generation and direct supply of pure hydrogen gas. Recently, direct methanol fuel cell (DMFC), based on the PEM-type cell appropriate for micro-scale electronics power has been developed (Varga, 2007; Ohashi et al.,2010; Kamarudin et al., 2009). But, direct methanol fuel cells, in its turn, have disadvantages, related with high temperature operation and formation of the $\mathrm{CO}$ pollutant gas. Moreover, using the organic polymer membrane in PEM-type direct-fueled cells and the high-cost platinum catalysts mitigates durability and increases a cost of fuel cells. Degradation of structural characteristics of polymer membrane material due to 
diffusion and electro-corrosion processes during electrochemical energy conversion in fuel cells becomes the major challenge in fuel cell basic research. Now, the fabrication technology of most portable electronic devices is based on standard micro-fabrication technique, but PEM-type fuel cells with polymer membrane are not readily integrated with this technique. On this view, it would be desirable to develop an inorganic proton conducting membrane for fuel cell with technology compatible with standard micro-fabrication techniques.

In order to get over the abovementioned disadvantages, we proposed to fabricate novel Schottky-type fuel cell for micro power generation, based on nano (micro)-porous silicon, operating at room temperature under direct exposition of hydrogen-containing gas and liquid compounds (Dzhafarov \& Can, 2000; Dzhafarov et al., 2002, 2004, 2005, 2008, 2010, 2011). Fabrication of porous silicon is compatible with micro-fabrication technology. Moreover, high porosity of porous silicon and very large surface-to-volume ratio (up to $10^{3}$ $\mathrm{m}^{2} . \mathrm{cm}^{-3}$ ) ensures the high proton conductivity comparable with that of polymer membrane Nafion ${ }^{\circledR}$. Additionally, such direct-fueled fuel cell can operate at room temperature under exposition hydrogen-containing compounds (including the sea-water) without formation of polluting gases.

The review of our and other published researches on fabrication and characterization of nanoporous silicon-based direct fuelled hydrogen fuel cells has been presented below. Moreover, the literature search concerning different types of hydrogen fuel cells is briefly given.

\section{Literature search}

Hydrogen is the most attractive and ultimate candidate for a future fuel and an energy carrier. Hydrogen is recognized as the environmentally desirably clean fuel of the futute since it can be used directly in different types of hydrogen fuel cells. In hydrogen fuel cells the electrical energy will be derived from the reaction of hydrogen and oxygen gases within the fuel cell to make water.

In the water electrilizer, electric current passed through water splits it into hydrogen and oxygen

$$
2 \mathrm{H}_{2} \mathrm{O} \rightarrow 2 \mathrm{H}_{2}+\mathrm{O}_{2} \quad(-285 \mathrm{~kJ} / \mathrm{mol})
$$

As opposite to reaction (1), production of water, heat, light and sometimes sound takes place when normally hydrogen burns reacting with oxygen from air

$$
2 \mathrm{H}_{2}+\mathrm{O}_{2} \rightarrow 2 \mathrm{H}_{2} \mathrm{O} \quad(+285 \mathrm{~kJ} / \mathrm{mol})
$$

Most fuel cells directly generate electricity using the chemical reaction between a fuel (hydrogen) and an oxidant (oxygen). In the hydrogen fuel cell the chemical reaction is exactly same to reaction (2), but instead of producing light and heat, electrical current is produced.

A fuel cell is an electrochemical energy conversion device which converts the chemical hydrogen and oxygen into water, and in the process it produces electricity. Most fuel cells today use hydrogen and oxygen as the chemicals (Mench, 2008; O'Hayre et al., 2009; Vialstich et al., 2003; Varga, 2007; Ohashi et al.,2010; Basu, 2007; Hoogers, 2003). Fuel cell provides a DC (direct current) voltage that can be used to power motors, lights or number of electrical appliances. The existing fuel cells are usually classified by their operating type and 
the type of electrolyte they use. The main types of fuel cells are given in Table 1 (Vielstich et el, 2009).

\begin{tabular}{|c|c|c|c|}
\hline Fuel Cell types & Fuel & Efficiency (\%) & Operating temp. (oC) \\
\hline PEM & $\mathrm{H}_{2}$ & $40-50$ & 80 \\
\hline \multirow{2}{*}{ Direct Methanol (DMFC) } & Methanol & \multirow{2}{*}{35} & \multirow{2}{*}{80} \\
\hline & Ethanol & & \\
\hline \multirow[t]{2}{*}{ Solid Oxide (SOFC) } & $\mathrm{H}_{2}, \mathrm{CO}$, & \multirow{2}{*}{$45-55$} & \multirow{2}{*}{700} \\
\hline & $\mathrm{CH}_{4}$ & & \\
\hline \multirow[t]{2}{*}{ Molten Carbonate (MCFC) } & $\mathrm{H}_{2}, \mathrm{CO}$, & \multirow{2}{*}{$50-60$} & \multirow{2}{*}{650} \\
\hline & $\mathrm{CH}_{4}$ & & \\
\hline Phosphoric Acid (PAFC) & $\mathrm{H}_{2}$ & $40-50$ & 190 \\
\hline Alkaline (AFC) & $\mathrm{H}_{2}$ & 50 & 50 \\
\hline
\end{tabular}

Table 1. Types of fuel cells

Polymer exchange membrane fuel cell (PEM or PEMFC). The PEM is the most likely candidate for portable and transportation applications. The PEM has a high power density and a relatively low operation temperature (ranging from 80 to $120^{\circ} \mathrm{C}$ ). PEM type fuel cell consists from two electrodes (the anode and cathode) and the electrolyte between them. The electrodes of the fuel cell are thin layers of material, with the platinum catalyst dispersed in carbon, which are applied to each side of the membrane, yielding what is known as a Membrane Electrode Assembly (MEA) (Fig.1). The anode, the negative post of the fuel, has several jobs. It conducts the electrons that are freed from the hydrogen molecules so that they can be used in an external circuit. It has channels etched into it that disperse the hydrogen gas equally over the surface of the catalyst. The cathode, the positive post of the fuel cell, has channels etched into it that distribute the oxygen to the surface of the catalyst. It also conducts the electrons back from the external circuit to the catalyst, where they can recombine with the hydrogen ions and oxygen to form water. The electrolyte is the proton exchange membrane. PEM can be made from either pure polymer membranes or from composite membranes where other materials are embedded in a polymer matrix. One of the most common and commercially available PEM material is Nafion, a DuPont product (US PATENT 5266421, granted 2008-11-30). The membrane presents a solid polymer having negative ionic sites attached to polymer chains. When such a membrane is hydrated (having water absorbed into it), hydrogen ions (protons) can move among the sites so that the protons can be transported across the membrane. The membrane only conducts positively charged ions and blocks electrons. For a PEMFC, the membrane must be hydrated in order to function and remain stable.

The catalyst (electrode) is a special material that facilitates the reaction of oxygen and hydrogen. It is usually made of platinum nano-particles very thinly coated onto carbon paper or cloth. The catalyst is rough and porous so that the maximum surface area of the platinum can be exposed to the hydrogen or oxygen. When an $\mathrm{H}_{2}$ molecule comes in contact with the platinum catalyst on the anode side, it splits $\mathrm{H}_{2}$ into two $\mathrm{H}^{+}$ions (protons) and two electrons (e-). The electrons are conducted through the anode, where they make their way through the external circuit (doing useful work such as turning a motor) and return to the cathode side of the fuel cell. On the cathode side of the fuel cell, oxygen gas $\left(\mathrm{O}_{2}\right)$ is being 
forced through the catalyst, where it forms two oxygen atoms. Each of these atoms has a strong negative charge. This negative charge attracts the two $\mathrm{H}^{+}$ions through the membrane, where they combine with an oxygen atom and two of the electrons from external circuit to form a water molecule $\left(\mathrm{H}_{2} \mathrm{O}\right)$. Chemistry of a fuel cell is following:

$$
\begin{array}{cc}
\text { Anode side: } & 2 \mathrm{H}_{2} \rightarrow 4 \mathrm{H}^{+}+4 \mathrm{e}^{-} \\
\text {Cathode side: } & \mathrm{O}_{2}+4 \mathrm{H}^{+}+4 \mathrm{e}^{-} \rightarrow 2 \mathrm{H}_{2} \mathrm{O} \\
\text { Net reaction } & 2 \mathrm{H}_{2}+\mathrm{O}_{2} \rightarrow 2 \mathrm{H}_{2} \mathrm{O}
\end{array}
$$

This reaction in a single fuel cell produces only about $0.7 \mathrm{~V}$. To get this voltage up a reasonable level many separate fuel cells must be combined to form a fuel cell stack. The described principles of fuel cell operation by using a sulphonated polystyrene ion-exchange membrane as the electrolyte are firstly realized by W. Thomas Grubb (General Electric Company, 1955).

\section{Membrane Electrode Assembly}

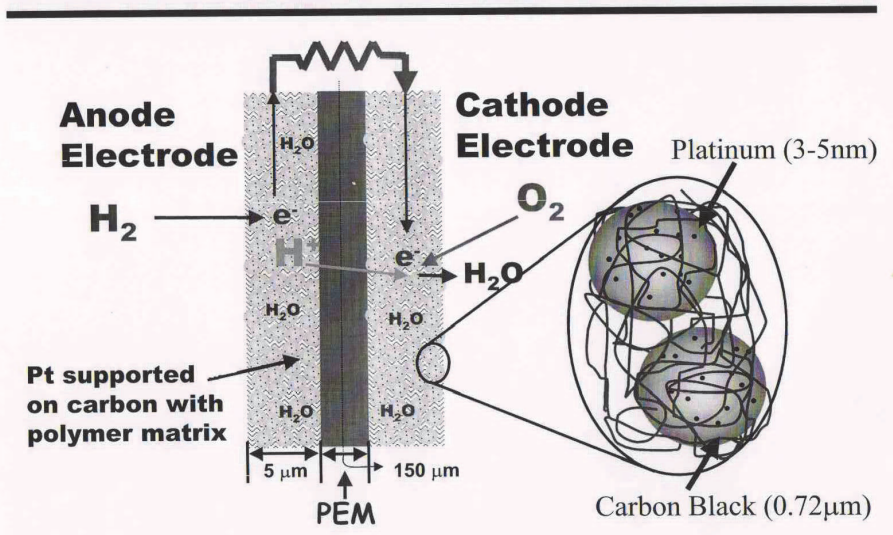

Fig. 1. Proton Exchange Membrane (PEM-type hydrogen fuel cell)

Direct-methanol fuel cell (DMFC) is a subcategory of proton-exchange membrane fuel cell in which methanol is used as the fuel. DMFC operates on dilute aqueous solutions, with reported workable devices allowing no more than 3\% methanol in water. Polymer electrolyte membranes are also used to construct Direct Methanol Fuel Cells (DMFC). The DMFC requires a relatively large amount of platinum to act as a catalyst, which makes this fuel cell expensive. The DMFC relies upon the oxidation of methanol on a catalyst layer to form carbon dioxide. Water is consumed at the anode and is produced at the cathode. Positive ions $\left(\mathrm{H}^{+}\right)$are transported across the proton exchange membrane - often made from Nafion - to the cathode where they react with oxygen to produce water. Electrons are transported through an external circuit from anode to cathode, providing power to connected devices. The half-reactions are:

$$
\text { Anode (oxidation): } \quad \mathrm{CH}_{3} \mathrm{OH}+\mathrm{H}_{2} \mathrm{O} \rightarrow 6 \mathrm{H}^{+}+6 \mathrm{e}^{-}+\mathrm{CO}_{2}
$$




$$
\begin{array}{cl}
\text { Cathode (reduction): } & 3 / 2 \mathrm{O}_{2}+6 \mathrm{H}^{+}+6 \mathrm{e}^{-} \rightarrow 3 \mathrm{H}_{2} \mathrm{O} \\
\text { Overall (redox reaction): } & \mathrm{CH}_{3} \mathrm{OH}+3 / 2 \mathrm{O}_{2} \rightarrow 2 \mathrm{H}_{2} \mathrm{O}+\mathrm{CO}_{2}
\end{array}
$$

During the methanol oxidation reaction carbon dioxide is formed, which strongly adsorbs onto the platinum catalyst, reducing the surface area and thus the performance of the cell. Platinum is very expensive and contributes to the high cost per kilowatt of these cells. Moreover, disadvantage of DMFC is that the methanol is toxic and flammable. The waste products of this type cells are carbon dioxide and water. The advantage of the DMFC consists in that methanol is a liquid fuel cell and is therefore easer to store and transport than hydrogen for PEM fuel cell. In terms of the amount of electricity generated, a DMFC can currently generate $300-500 \mathrm{~mW} / \mathrm{cm}^{2}$. DMFC uses the same type of electrolyte as PEM fuel cell, but require thicker membranes and greater loading (density) of catalysts. It operates at between 80 and $120^{\circ} \mathrm{C}$ with an efficiency of up $40 \%$. DMFC based micro fuel cells can be used for portable electronics such as mobile phones, digital camera, laptop computers etc. Military applications of DMFC are an emerging application since they have low noise and thermal signatures. These applications include power for soldier-carried tactical equipment, battery chargers, and autonomous power for test and training instrumentation.

Solid oxide fuel cell (SOFC). In the SOFC design, the anode and cathode are separated by an electrolyte that is conductive to oxygen ions but non-conductive to electrons. The electrolyte is typically made from zirconia doped with yttria. It is best suited for large-scale stationary power generators that could provide electricity for factories or town. This type of fuel cell operates at very high temperatures $\left(700-1000{ }^{\circ} \mathrm{C}\right)$ and uses $\mathrm{H}_{2}, \mathrm{CO}$ or $\mathrm{CH}_{4}$ as fuel. Advantages of SOFC are high power density $\left(200-2000 \mathrm{~mW} / \mathrm{cm}^{2}\right)$, fuel flexibility and the possibility of internal reforming. Hydrogen is generated on the anode porous surface by steam reforming of , for example, methane (Bove \& Ubertini, 2008)

$$
\mathrm{CH}_{4}+\mathrm{H}_{2} \mathrm{O} \rightarrow \mathrm{CO}+3 \mathrm{H}_{2}
$$

and subsequent water gas shift

$$
\mathrm{CO}+\mathrm{H}_{2} \mathrm{O} \rightarrow \mathrm{CO}_{2}+\mathrm{H}_{2}
$$

The transition metals, such as $\mathrm{Ni}$ in the anode play role of catalyst. The direct electrooxidation of the fuel

$$
\begin{gathered}
\mathrm{CH}_{4}(\mathrm{~g})+4 \mathrm{O}^{2-} \rightarrow \mathrm{CO}_{2}(\mathrm{~g})+2 \mathrm{H}_{2} \mathrm{O}(\mathrm{g})+8 \mathrm{e}^{-} \\
\mathrm{CH}_{4}(\mathrm{~g})+3 \mathrm{O}^{2-} \rightarrow \mathrm{CO}(\mathrm{g})+2 \mathrm{H}_{2} \mathrm{O}(\mathrm{g})+6 \mathrm{e}^{-} \\
\mathrm{CO}(\mathrm{g})+\mathrm{O}^{2-} \rightarrow \mathrm{CO}_{2}(\mathrm{~g})+2 \mathrm{e}^{-}
\end{gathered}
$$

may take place under dry conditions though processing in elementary steps as does the steam reforming. A single cell operated with hydrogen and oxygen provides at equilibrium the open-circuit voltage of $1.2 \mathrm{~V}$ at standard conditions $(\mathrm{T}=273 \mathrm{~K}, \mathrm{p}=1 \mathrm{~atm})$. The cell voltage depends on the used fuel, operation temperature and pressure. The open-circuit voltage of SOFC operating on hydrogen and oxygen is about $0.9 \mathrm{~V}$ at $1000^{\circ} \mathrm{C}$

Alkaline fuel cell (AFC) with potassium hydroxide $(\mathrm{KOH})$ electrolyte is one of oldest designs for fuel cell. The AFC is very susceptible to contamination, so it requires pure hydrogen and oxygen. It is also very expensive, so this type of fuel cell is unlikely to be commercialized. 
Molten-carbonate fuel cell (MCFC) operates in manner of SOFC, expect the electrolyte consists of liquid (molten) alkaline carbonate $\left(\mathrm{NaHCO}_{3}\right)$, which is an oxidizing agent. $M C F C$ is also best suited for large stationary power generators. It uses $\mathrm{H}_{2}, \mathrm{CO}$ or $\mathrm{CH}_{4}$ as fuel and operates at $600^{\circ} \mathrm{C}$ that makes the design a little less expensive than that of $A F C$.

Phosphoric-acid fuel cell (PAFC) with molten $\mathrm{H}_{3} \mathrm{PO}_{4}$ electrolyte has potential for use in small stationary power-generation systems. It operates at a higher temperature $\left(200^{\circ} \mathrm{C}\right)$ than polymer exchange membrane fuel cell.

At the moment, the further increase in functionality of portable devices is severely hindered by the limits energy sources. Higher energy densities, smaller size, lower cost per watt and faster charging are the wish list. Fuel cells have the potential to increase the energy density of such devices by a factor of 3 to 10 compared to presently used lithium batteries. They are more user friendly since recharging is not required. Most of the fuel cell research activities have been up to now devoted to large power automotive and stationary applications.

During the past years, portable versions of the fuel cells have emerging. The most promising miniature fuel cell is the direct methanol fuel cell (Crawley, G., 2007; Kamardin et el., 2009). DMFC is inexpensive, convenient, does not require pressurized hydrogen gas and provides good electrochemical performance. This is still large in size compared to an electrochemical battery and further reduction will be needed. Charging consists of replacing on the fly. This provides a continued source of energy similar to fueling a car.

A large number of companies continue to work in developing and fabricating of direct methanol fuel cells. Most of such fuel cells are on stage of "in development" or testing phase. Toshiba unveiled a prototype DMFC for a laptop (http://www.batteryuniversity .com/parttwo). The company gave no indication as to when the product would be commercialization available. A direct battery replacement that offers high power, small size and competitive price is still several years away. As good as the fuel cell may look from the outside, 15-years of experiments has not solved number of persistent problems. One is the slow start-up; another is the low electrochemical activity at the anode. This is especially apparent with the DMFC. Deposition of $\mathrm{CO}_{2}$, forming during operation of DMFC (see eq.(26)) results in decrease of active the anode surface and thereby decreases the performance and durability of the fuel cell. Each cell produces about one volt and when loaded, the relatively high internal resistance of membrane-electrode-assembly (MEA) sandwich causes the voltage drops quickly. Miniature DMFC of 1 watt for portable communication systems is developed by 'Motorola Labs" (http://www.fuelcells.org/MicroMarket.pdf).

Fuel cells might be the answer to our problems, but first scientists will have to sort out a few major issues: (a) Cost. Chief among the problems associated with fuel cells is how expensive they are. Hydrogen is the most common element in the universe. However, hydrogen does not naturally exist on Earth in its elemental form. Engineers and scientists must produce pure hydrogen from hydrogen compounds, including fossil fuels or water. In order to extract hydrogen from these compounds, we have to exert energy. The required energy may come in the form of heat, electricity or even light. This increases cost of energy produced by fuel cells. Additionally, for PEMFC systems, proton exchange membranes, precious metal catalysts (usually platinum), gas diffusion layers and bipolar plates make up 70 percent of a system's cost. In particular, researchers must either decreases the amount of platinum needed to act as a catalyst or find an alternative. (b) Durability. Researchers must develop PEMFC membranes that are durable and can operate at temperatures greater than $100^{\circ} \mathrm{C}$ and still function at sub-zero ambient temperatures. Currently membranes tend to degrade 
while fuel cells cycle on and off, particularly as operating temperatures rise. (c) Hydration. Because of PEMFC membranes must be hydrated in order to transfer hydrogen protons, researchers must find a way to develop fuel cell systems that can continue to operate in subzero temperatures, low humidity environments and high operating temperatures. At around $80^{\circ} \mathrm{C}$ hydration is lost without a high-pressure hydration system.

In past years, there has been considerable interest in development of micro fuel cells for portable electronic devices due to their advantages over conventional batteries, including rapid recharging and much higher stored energy density. In the next 10 years the international technology roadmap for semiconductors (http://public.its.net) forecasts a decrease of the voltage required to power the working of microcircuits toward $0.6 \mathrm{~V}$. The use of miniature fuel cells appears an attractive way to power portable electronics with a clean and refillable energy source. Among all types of fuel cells only two (PEM and DMFC) are suitable for miniaturization. The limitation principally comes from the working temperature required to be lower than $100^{\circ} \mathrm{C}$. One of them is the proton exchange membrane (PEM) fuel cell. A key element of a PEMFC is the membrane that must behave high conductivity for protons and be impermeable to all other present species.

At the present time, the best conductivity $\left(0.08{\left.\mathrm{~S} . \mathrm{cm}^{-1}\right)}^{-}\right.$is reached by Nafion ${ }^{\circledR}$ perfluorosulfonated membranes. However the high cost and the geometric instability during hydration are only some of the severe constraints of such polymers. The nature of the proton conductive process in an ionometric membrane such as Nafion ${ }^{\circledR}$ is not still completely understood. The present consensus (Bunker et el., 1998) is to describe a Nafion ${ }^{\circledR}$ membrane as a skeleton of hydrophobic chains including connected hydrophilic domains containing water molecules. The diameter of the connecting channels is about $3 \mathrm{~nm}$. The low stiffness of this skeleton is responsible for the swelling if the membrane with hydration in response to the molecular interactions. Moreover, this type of polymer membranes cannot be patterned with standard microelectronic technology.

A number of alternative solutions have been proposed to avoid these problems, one of them being the use of organic-inorganic hybrid membranes. The literature reports original research like \{hybrid silica/ Nafion $\left.{ }^{\circledR}\right\}$ membranes (Jung, 2002) or a porous silica membrane filled with sulfonated polyelectrolyte (Yamaguchi et el., 2002). Yet these are not suitable to obtain easily integrated miniature cells.

Problems of performance, reliability, durability, a restricted allowable ambient-temperature range for operation and cost of miniature PEM fuel cells, particularly of DMFC, for portable devices were related with:

- materials of polymer membrane and platinum catalyst,

- poisoning the platinum catalyst by carbon dioxide during fuel cell operation,

- the large resistance drop in the membrane-electrode-assembly,

- compatibility of DMFC technology fabrication with standard micro technology.

These problems are not solved and require researches which must be focused on new porous materials and structures. Last time the new porous silicon-based fuel cell has attracted high attention.

\section{Preparation and properties of porous silicon}

Porous silicon (PS) layer on monocrystalline Si substrate and its manufacture by the technique of electrochemical etching of silicon substrate in HF solution or by chemical etching in $\mathrm{HF}-\mathrm{HNO}_{3}$ mixture are known as early as from 1956 (Canham, 1997; Feng \& Tsu, 
1994). A great interest to porous silicon arisen in the 90-s of 20-th century is caused by observation of strong visual photoluminescence and electroluminescence at room temperature. Electrochemical etching of silicon is attractive because of the possibility to tune the pore size from a few nanometers to a few tens of micrometers, just by choosing wafer doping level and etching conditions. Moreover, a wide range of porous layer thickness, porosities, surface areas and morphologies can be formed depending on the etching conditions. The bulk silicon was shown modifies during the etching to sponge-like structure with silicon columns and hydrogen covered pores.

The simplest electrochemical cell is shown in Fig. 2. The Si wafer acts as the anode and the platinum is the cathode. The thickness of porous silicon layer on Si substrate is determined by duration of etching. The porosity, i.e. the void fraction in the porous layer is determined by the current density (about $10-100 \mathrm{~mA} / \mathrm{cm}^{2}$ ), composition electrolyte, resistivity and the doping density of Si substrate.

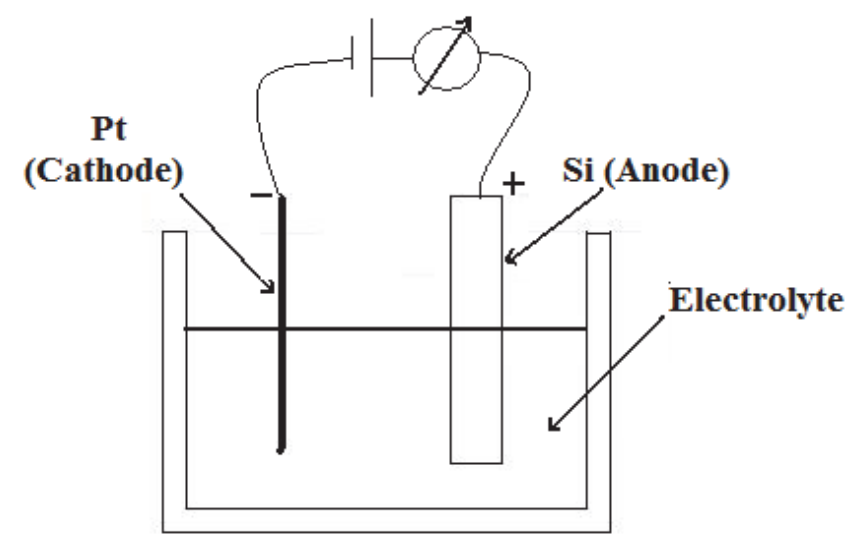

Fig. 2. Cross-sectional view of lateral anodization cell.

The anodic reaction on the Si substrate can be written during pore formation as (Beale et. al., 1985)

$$
\mathrm{Si}+6 \mathrm{HF} \rightarrow \mathrm{H}_{2} \mathrm{SiF}_{6}+\mathrm{H}_{2}+2 \mathrm{H}^{+}+2 \mathrm{e}^{-}
$$

Silicon atoms are dissolved as $\mathrm{SiF}_{6}{ }^{2-}$ requires the presence of $\mathrm{F}$ - ions (from HF solution) and positively charges holes (from the silicon wafer) at the silicon interface. Concentration of holes in p-Si is sufficiently high (about $10^{14}-10^{18} \mathrm{~cm}^{-3}$ ) and this case the nano-size pores were formed. Concentration of holes in n-Si is very small (about $10^{2}-10^{6} \mathrm{~cm}^{-3}$ ) and therefore generation of holes is possible due to illumination of n-Si substrate.

The structure and size of pores in porous silicon layer formed on n-Si substrate differ from those for layer on $\mathrm{p}$-Si. If electrochemical etching was carried out at relatively low current density $\left(10-80 \mathrm{~mA} / \mathrm{cm}^{2}\right)$, then the local dissolution of silicon surface takes place. Herewith, pore formation begins on surface defects of $\mathrm{Si}$ and further growth of pores into silicon substrate proceeds due to the holes diffusion to Si-electrolyte interface. In the case of large current density $\left(0.5-0.8 \mathrm{~A} / \mathrm{cm}^{2}\right)$ when the amount of holes moving to Si-electrolyte interface is very high, the etching of top regions of $\mathrm{Si}$ substrate is preferred. It ensures the 
uniform etching of silicon surface and formation a smooth surface of substrate (the so-called the electropolishing process). The raising the current density above the critical value at the end of anodization process results in a detachment of the porous silicon film from $\mathrm{Si}$ substrates. The behavior at high current densities turns out to be useful to produce porous silicon free-standing layers. The anodic reaction during the electropolising can be written as

$$
\mathrm{Si}+6 \mathrm{HF} \rightarrow \mathrm{H}_{2} \mathrm{SiF}_{6}+4 \mathrm{H}^{+}+4 \mathrm{e}^{-}
$$

Pores, depending on the its diameter, denoted as micropores $(\mathrm{R}<2 \mathrm{~nm})$, mesopores $(2 \mathrm{~nm}<\mathrm{R}$ $<50 \mathrm{~nm}$ ) and macropores ( $\mathrm{R}>50 \mathrm{~nm}$ ). Under illumination the pore size dependent on doping density and anodization conditions, with diameters in the range $100 \mathrm{~nm}-20 \mu \mathrm{m}$ (macropores). The crystalline structure of porous silicon presents a network of silicon in nano-(micro)sized regions surrounded by void space with a very large surface-to-volume ration (up to $10^{3} \mathrm{~m}^{2} \mathrm{~cm}^{-3}$ ) (Herino, 1998). The structure of porous silicon is like a sponge where quantum effects plays fundamental role (a quantum sponge) (Bisi et el., 2000). The pore surfaces are covered by silicon hydrides and silicon oxides and therefore they are very chemical active. These features of porous silicon (a quantum system, a sponge structure and an extremely large pore surfaces) ensure many possible applications, such as light emitting diode, sensor, hydrogen fuel cell and other applications.

PS layers with a thickness of $10-20 \mu \mathrm{m}$ and an average porosity of 40 to $80 \%$ were prepared on n-type (111) Si substrates $\left(\rho=1 \times 10^{-2} \Omega \mathrm{cm}\right)$ by anodic etching in $\mathrm{HF}: \mathrm{H}_{2} \mathrm{O}=1: 3$ solution at a dc current of about $15 \mathrm{~mA} \mathrm{~cm}^{-2}$ under white-light illumination (Dzhafatov et al., 2004). For some measurements, the PS films were then detached from the Si substrate by electro polishing in the same solution with a current density of $0.8-1.0 \mathrm{~A} \mathrm{~cm}^{-2}$. The free-standing PS films were characterized by porosity, thickness and resistivity measurements. The average porosity was measured by a gravimetry technique. Resistivity and charge carrier concentration measurements were carried out on the free-standing PS layers attached to a dielectric substrate (glass) by using the Van der Pauw technique. In or In-Ga alloy was used as an ohmic contact to the PS layer. Morphological characterizations of the PS surface were performed by scanning electron microscopy.

The average porosity $(\mathrm{P})$, i.e. the avoid fraction in the porous layer, can be obtained by gravimetry using the equation

$$
\mathrm{P}=\left(\mathrm{m}_{1}-\mathrm{m}_{2}\right) /\left(\mathrm{m}_{1}-\mathrm{m}_{3}\right)
$$

Here $m_{1}$ is Si sample mass before the anodization etching, $m_{2}$ just after etching and $m_{3}$ after the removal of the porous layer by electro-polishing or after a rapid dissolution of the whole porous layer in a $3 \% \mathrm{KOH}$ solution. Guessing the porous silicon mass $\mathrm{m}_{\mathrm{PS}}$, the average porosity can be also determined by using the equation

$$
\mathrm{P}=1-\mathrm{m}_{\mathrm{PS}} / \rho S \mathrm{~d}=\left(\mathrm{m}_{1}-\mathrm{m}_{\mathrm{PS}}\right) / \mathrm{m}_{1}
$$

One can also get the porous silicon layer thickness $d$ using the equation

$$
\mathrm{d}=\left(\mathrm{m}_{1}-\mathrm{m}_{3}\right) / \rho S
$$

where $\rho$ is the Si density $\left(2.33 \mathrm{~g} / \mathrm{cm}^{3}\right)$ and $S$ is the etched surface. Fig. 3. shows the SEM micrographs of porous silicon surface.

The electrical measurements of the free-standing PS layers with $65 \%$ porosity $(300 \mathrm{~K}, 45 \%$ $\mathrm{RH}$ ) gave values of $\rho=1.8 \times 10^{6} \Omega \mathrm{cm}$ for resistivity, $\mathrm{p}=9.6 \times 10^{12} \mathrm{~cm}^{-3}$ for hole concentration, and $\mu=0.36 \mathrm{~cm}^{2} /(\mathrm{V} \mathrm{s})$ for hole mobility (Dzhafarov \& Aydin , 2009). 


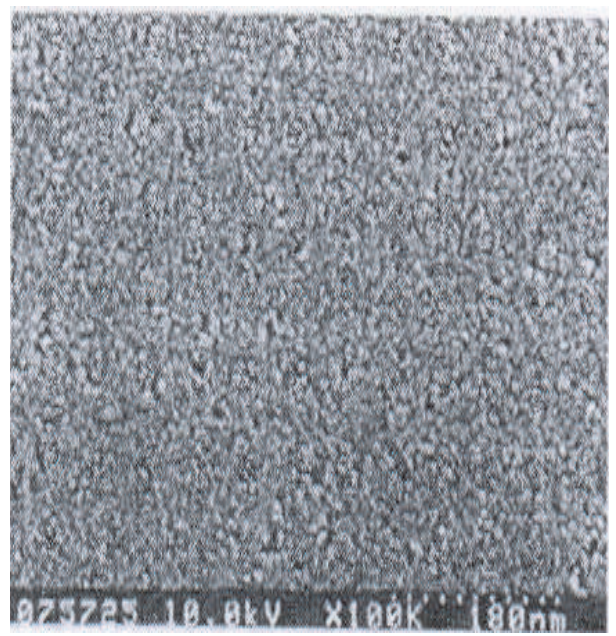

Fig. 3. Scanning electron microscopy of porous silicon layer surface.

Fig. 4. illustrates FTIR spectrum of free-standing PS film of thickness $12 \mu \mathrm{m}$ measured at room temperature (Dzhafarov \& Can, 2000). The peaks related with absorption on vibration of Si-H $\left(2100 \mathrm{~cm}^{-1}\right)$ and $\mathrm{Si}-\mathrm{O}$ bonds $\left(1100 \mathrm{~cm}^{-1}\right)$ located on pore surfaces were observed from Fig. 4. These bonds play an important role in regulating optical, electrical and gas sensing properties of porous silicon.

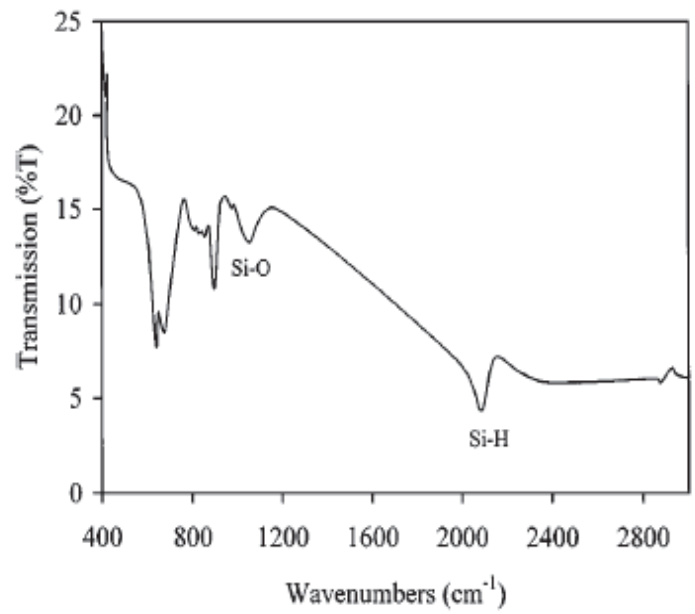

Fig. 4. FTIR spectrum of porous silicon film (300 K).

The effect of isothermal annealing of free-standing PS films on changes of intensity of absorption coefficient of Si-H $\left(2100 \mathrm{~cm}^{-1}\right)$ and Si-O $\left(1100 \mathrm{~cm}^{-1}\right)$ peaks is used for estimation of diffusion coefficient from equation (Abdullaev \& Dzhafarov, 1987)

$$
\mathrm{Q}=2 \Pi^{-0.5} \mathrm{SN}_{\mathrm{o}}(\mathrm{Dt})^{0.5}
$$


Here $Q$ is the total quantity of hydrogen (or oxygen) penetrating from air into PS film (or out-diffusing from PS film), $\mathrm{N}_{\mathrm{o}}=\mathrm{N}(0, \mathrm{t})$ is the surface concentration on an external surface of PS film and $S$ is the area of sample. Results of these measurements showed that in the range of $65-185^{\circ} \mathrm{C}$ the temperature dependence of hydrogen and oxygen diffusion coefficient along the porous surfaces are described as (Dzhafarov \& Can, 2000)

$$
\begin{aligned}
& D(H)=5 \times 10^{-10} \exp (-0.37 \mathrm{eV} / \mathrm{kT}) \\
& D(O)=1.3 \times 10^{-8} \exp (-0.50 \mathrm{eV} / \mathrm{kT})
\end{aligned}
$$

The activation energy for diffusion of hydrogen along the porous surfaces estimated from response (or recovery) $\mathrm{V}_{\mathrm{oc}}-\mathrm{t}$ curves for $\mathrm{Au} / \mathrm{PS} / \mathrm{Si}$ cells under humid ambient $(90 \% \mathrm{RH})$ is $0.34 \mathrm{eV}$ (Dzhafarov \& Aydin, 2010).

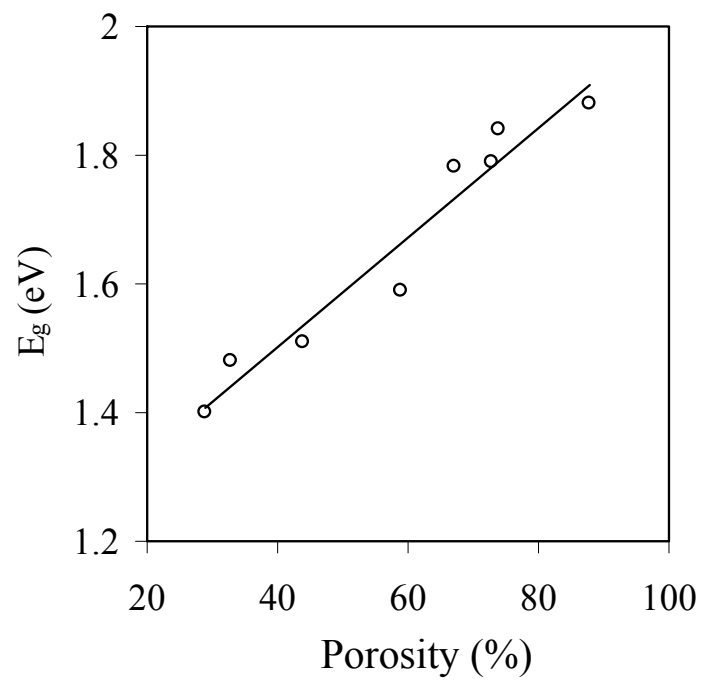

Fig. 5. Energy band gap in depending on porosity of PS film (40\% RH, $300 \mathrm{~K})$.

Fig. 5. shows the effective energy gap in dependency on porosity of the free standing PS films, calculated from extrapolation of the high energy part of $\left\{\mathrm{a}^{2}(h \mathrm{v})^{2}-h \mathrm{v}\right\}$ spectra (Dzhafarov et el., 2007). Near linear increase of band gap from 1.4 to $1.9 \mathrm{eV}$ with rising of porosity of PS films in the range of $30-90 \%$ is observed. Data on Fig. 5. concerning a increase of the energy gap in dependency on porosity of PS films, can be explained by a model including the quantum confinement of carriers in the PS microcrystallites, causing the widening of the Si band gap.

\section{Porous silicon-based hydrogen fuel cells}

Most of PEM-type fuel cells have used Nafion ${ }^{\circledR}$ as the proton exchange membrane, yet it does not seem to be right solution. Indeed Nafion ${ }^{\circledR}$ polymer membranes are inadequate to standard micro fabrication techniques. Recent our and other investigations (Dzhafarov et 
al., 2008, 2010; Dzhafarov \& Aydin Yuksel, 2011; Chu et al., 2007; Pichonat et al., 2005; Gyoko et al., 2005; Lee et el., 2007; Moghaddam et el., 2009; Hayase et el., 2004; Starkov et el., 2006) have shown the growing interest to the development of porous silicon-based miniature fuel cells for chip-scale power. The main advantage of porous silicon membranes consists in suitable to obtain easily integrated miniature cells.

The potential advantages of porous silicon for fuel cell applications are follows:

a. unique combination of the crystal structure and the huge surface to volume ratio (about of $\left.1000 \mathrm{~m}^{2} / \mathrm{cm}^{3}\right)$;

b. strong surface chemical reactivity, significant change of porous silicon surface as a result of different kinds of treatment (thermal, chemical, optical etc.);

c. high ionic conductivity over the pores;

d. possibility to make 3D structures and proton-conducting membranes;

e. opportunity to modify the morphology by the control of the porous dimensions from nano- to micro-scale;

f. simplicity and cheapness of the technology that could be compatible with silicon IC technology.

Taking into account this, porous silicon has proved to be a promising material to replace traditional Nafion-based proton exchange membrane, as this material provides a porous matrix that can be functionalized for further proton exchange behavior. Nowadays, investigations of porous silicon based miniature fuel cells is the conceptual stage and the number of reports on fuel cells with porous silicon membrane is limited. Recently some novel applications of porous silicon have been discovered utilizing other interesting characteristics (Stewart \& Buriak, 2000). Nanoporous silicon is readily formed by anodic etching in hydrofluoric acid. The nanoscale pore sizes that can be achieved in porous silicon by anodic etching may provide a conduit for proton transport. In an acidic aqueous media, such as a formic acid, the silicon surface is readily oxidized leaving hydroxyl terminated pore surfaces. This hydroxylated surface is known to be acidic (Cook, 1990) and should allow for proton conduction through the nanoporous. Furthermore, the nanoscale diameter of the pores may serve as a diffusion barrier preventing larger molecules from going through. In principle, the viability of porous silicon as a proton conductor as well as a diffusion barrier to fuel molecules can be further promoted by the function of porous silicon (Song \& Sailor, 1999). A major advantage of porous silicon is its compatibility with conventional silicon micro-fabrication technology, which presents the possibility of fabricating different components of a fuel cell or even a fuel cell and its supported devices in a monolithic fashion. Porous silicon should be stable at elevated temperatures, unlike many polymeric materials. The use of porous silicon as a gas diffusion layer (Maynard \& Meyers, 2000) or a support for catalysts (D'Arrigo et el., 2003) has been demonstrated.

The maximum power density of $47 \mathrm{~mA} / \mathrm{cm}^{2}$ and open-circuit voltage of $0.76 \mathrm{~V}$ for PEM-type fuel cell with porous silicon membrane and Pt-based catalyst on both side of PS membrane were reported (Moghaddam et al., 2009). This has been achieved due to development of a technique for self-assembly of molecules with functional end group inside high aspect ratio nanoporous $(7-10 \mathrm{~nm})$ within a porous silicon membrane.

Micro direct ethanol fuel cell with porous silicon electrodes and Nafion membrane have been described (Aravamudhan et el., 2005). The structure consists of a porous silicon anode (fuel micro-column) and a porous silicon cathode (air micro-column) sandwiching a proton exchange membrane (Nafion $115^{\mathrm{TM}}$ ). Platinum is deposited on both the micro-columns to act 
both as a electrocatalyst and a current collector. Ethanol has been used as fuel. The hybrid type \{porous silicon/Nafion/porous silicon\} fuel cell generated an open-circuit voltage of $260 \mathrm{mV}$ and maximum power density of $8.1 \mathrm{~mW} / \mathrm{cm}^{2}$ at room temperature with a fuel supply of $5 \mu \mathrm{L}$ of $8.5 \mathrm{M}$ ethanol solution.

The complicated design of fuel cell with porous silicon membrane have been studied in (Chu et al., 2007). The three-layer catalysts $\{\mathrm{Nafion}+\mathrm{Pd} / \mathrm{Au}+\mathrm{Pd} / \mathrm{Au}\}$ were painted directly onto both the porous silicon membrane surfaces. A solution of $5 \mathrm{M}$ formic acid with $0.5 \mathrm{M}$ sulfuric acid was used as the fuel at the anode. The cathode was exposed to ambient air for oxygen supply. For this micro fuel cell peak power about of $94 \mathrm{~mW} / \mathrm{cm}^{2}$ have been reached. However, using complicated and high-cost catalysts in this type of fuel cell makes problematic its application.

A new way of making miniature fuel cell, using a porous silicon membrane with a silane grafted on pores walls has been demonstrated in (Pichonat et al., 2005). Tests of fuel cell with the chemical grafting of molecules bearing acid groups on the pore walls of a porous silicon membrane allow to achieve power density of $17 \mathrm{~mW} / \mathrm{cm}^{2}$. Measurements have been carried out under $\mathrm{H}_{2}$ feeding that is provided by $20 \% \mathrm{NaOH}$ solution electrolysis and $\mathrm{O}_{2}$ directly by ambient air.

The porous silicon wafer filled with sulfuric acid solution or Nafion as a proton conduction membrane for micro fuel cells have been developed (Gyuko et al., 2005). For the fuel cell filled with sulfuric acid solution $(20 \%)$ or Nafion, assembled into the $\mathrm{H}_{2} /$ air ambient the maximum power density of $12.75 \mathrm{~mW} / \mathrm{cm}^{2}$ and $1.27 \mathrm{~mW} / \mathrm{cm}^{2}$ were achieved respectively.

Porous silicon as a gas diffusion layer (GDL) have been used in a micro direct methanol fuel cell (Lee et al., 2007). Porous silicon was prepared by photoelectrochemical etching of silicon wafer. The maximum power density of DMFC of $9.37 \mathrm{~mW} / \mathrm{cm}^{2}$ was obtained under using $2 \mathrm{M}$ methanol as fuel.

The hybrid type of \{porous silicon layer/ Nafion 112\} hydrogen fuel cell has been developed (Hayase et al., 2004). The fuel channels were fabricated by photolithographic pattering and subsequent wet etching of silicon. The porous layer was formed by anodization of silicon from the polymer electrolyte membrane. The maximum power density of $1.5 \mathrm{~mW} / \mathrm{cm}^{2}$ and open-circuit voltage of $840 \mathrm{mV}$ were observed by hydrogen feed.

A layer of carbon nanofibers and nanotubes formed on the surface of macropores in silicon, in which the pore cross section and structure varies with depth, have been offered (Starkov et al., 2006). The obtained structure, in authors opinion, can be serve as a basis for the development of electrodes for polymer cells with a specific of conducting surface area.

Porous silicon also can be used as hydrogen reservoirs. Concentration of atomic hydrogen chemically bound to the specific surface of porous silicon (of $95 \%$ porosity with nanocrystallite dimensions of $2 \mathrm{~nm}$ ) is about $66 \mathrm{mMol} / \mathrm{g}$ (Lysenko et al., 2005).

\section{Metal/porous silicon/silicon -based direct hydrogen fuel cells}

Most previous works on fuel cells using the porous silicon has been focused on direct methanol fuel cell (DMFC) with an expensive Pt, Pt-Ru or Pd as catalyst (Aravamadhan et al., 2005; Gold et al., 2004). New type of fuel cell based on \{metal/porous silicon/silicon\}Schottky type structure has been proposed and realized (Dzhafarov et al., 2005; 2008; 2010; 2011). Such fuel cell uses the porous silicon layer as membrane, Au film as electrode-catalyst and operates at room temperature under direct supplying of different hydrogen-containing gaseous and liquid fuels. 
Cell fabrication. The Au/PS/Si structures were fabricated by the evaporation of a thin Au film onto the PS surface with a porosity of $65 \%$ at room temperature by using the electronbeam technique (Dzhafarov et al., 2004). The thickness of the deposited Au film was $150 \mathrm{~nm}$, as obtained by measurements during the evaporation using a deposition controller (Inficon, Leybold). Current-voltage (I-V) characteristics, open-circuit voltage $\left(\mathrm{V}_{\mathrm{oc}}\right)$, and short-circuit current density $\left(\mathrm{J}_{\mathrm{sc}}\right)$ of the $(\mathrm{Au}) / \mathrm{PS} / \mathrm{Si}$ and PS/Si structures were measured at room temperature in air (300 K, 45\% relative humidity $(\mathrm{RH})$ ) as well as for different gas atmospheres (humid, $\mathrm{CO}$, and $\mathrm{H}_{2} \mathrm{~S}$ ) in the measuring cell. The concentrations of $\mathrm{CO}$ and $\mathrm{H}_{2} \mathrm{~S}$ were measured using a BW Defender Multi-Gas Detector. The gas-stimulated open circuit voltage $\left(\mathrm{V}_{\mathrm{oc}}\right)$ and short-circuit current density $\left(\mathrm{J}_{\mathrm{sc}}\right)$ for the contacts to the Au film and PS layer (or Si substrate) were measured directly by a Thurlby-1503 digital multimeter. (Fig. 6). $\mathrm{RH}$ in the cell was measured with an Extech- 44470 hygro thermometer. The photosensitive properties of the $\mathrm{Au} / \mathrm{PS}$ structures were analysed by measuring the I-V characteristics in the dark, in daylight, and under tungsten-halogen lamp illumination $150 \mathrm{~mW} \mathrm{~cm}^{-2}$ ). All the investigated structures exhibited very weak photosensitivity. The value of the open-circuit photo voltage in daylight and under tungsten-halogen lamp illumination was 1-3 $\mathrm{mV}$. Therefore, gas-sensitive measurements were performed under daylight illumination

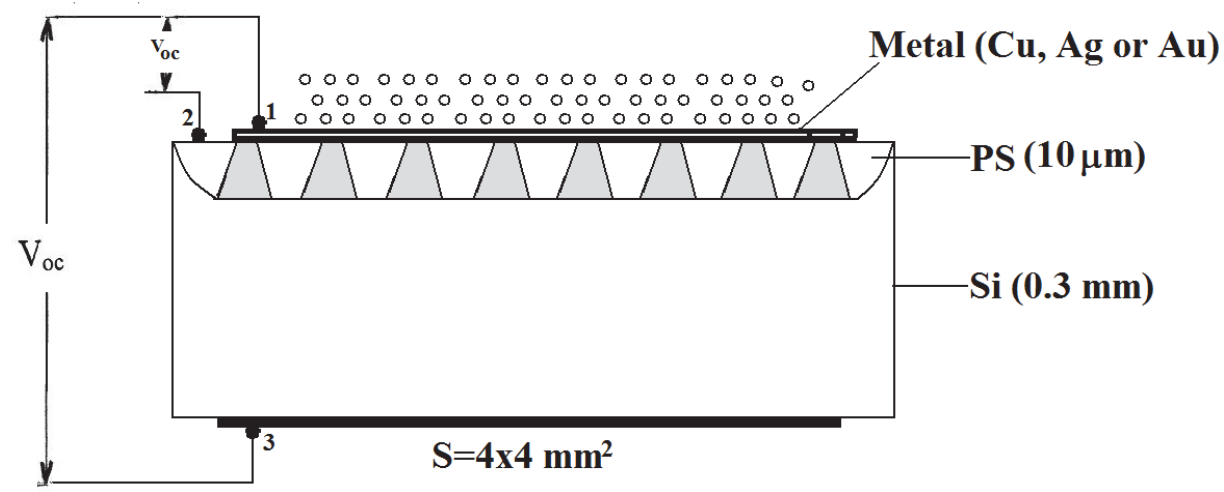

Fig. 6. Schematic sketch of Metal/PS/Si structure.

SEM micrographs of the PS and Au/PS surfaces are shown in Fig.7. Here the bright and relatively dark regions are the tops of silicon walls and intervals containing no of PS, respectively. The larger dimensions of the bright islands on the Au/PS surface than on the PS surface may be caused by 2-3 neighboring islands covered by unbroken gold film. We suppose that gold atoms deposit primarily on the external surface of the porous silicon layer at the initial stage of evaporation. Then, as the gold film thickness on the external surface of the porous silicon increases, the pores are fully closed by gold film.

The current-voltage characteristics of $\mathrm{Au} / \mathrm{PS} / \mathrm{Si}$ structure showed the good rectifying properties. The typical reverse I-V characteristics of Au/PS structure in air ambient at 45 $\% \mathrm{RH}, 70 \% \mathrm{RH}, 83 \% \mathrm{RH}, 90 \% \mathrm{RH}$ and $99 \% \mathrm{RH}$ at room temperature are presented in (Fig. 8) (Dzhafarov et el., 2004).

It is seen that the reverse currents considerably increase with the rising of relative humidity. The value of current at $99 \% \mathrm{RH}$ (for $2 \mathrm{~V}$ ) increases in comparison with that at $45 \% \mathrm{RH}$ (for 
2V) by factor 12. It will be noted that PS/Si structures (without $\mathrm{Au}$ film) showed a weak rectifying characteristics and the weak humidity-sensitive properties.

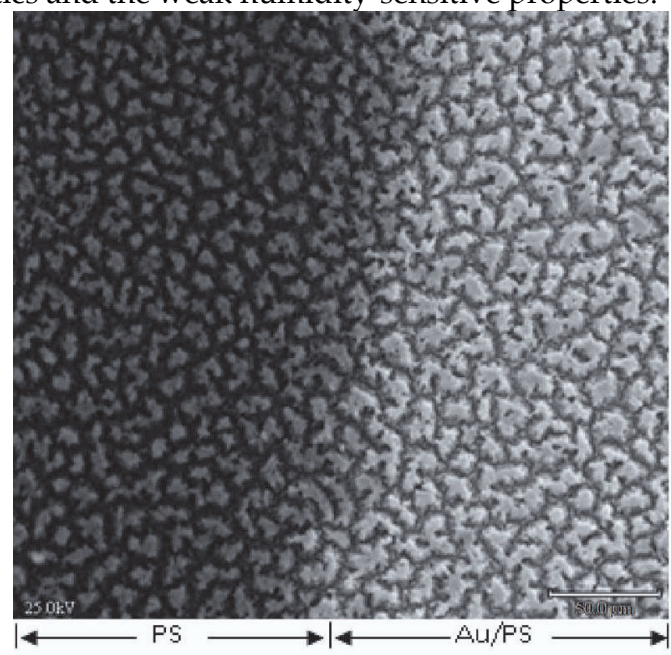

Fig. 7. SEM micrographs of PS and Au/PS surfaces.

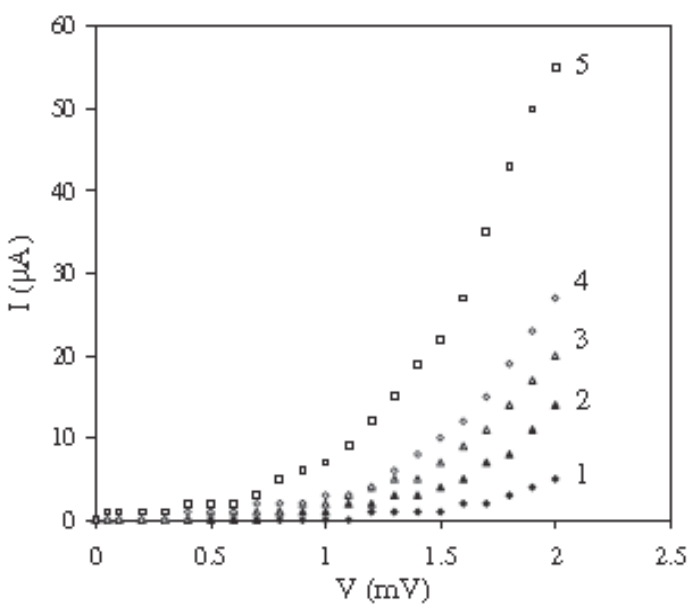

Fig. 8. Reverse I-V characteristics of Au/PS/Si structure in humid ambient: (1) 45, (2) 70, (3) 83, (4) 90 and (99) \% RH.

The humidity (hydrogen)-voltaic effect i.e. generation of a the open-circuit voltage between contacts to Au film and Si under humidity (hydrogen-containing gas) exposition is observed for Au/PS/Si Schottky-type structure. The similar effect is also discovered for Ag/PS/Si and Cu/PS/Si structures (Dzhafarov \& Can, 2000; Dzhafarov et al., 2002). Fig. 9 illustrates the open-circuit voltage in dependency on the relative humidity for one of such Au/PS/Si structures. It is seen that the $\mathrm{V}_{\mathrm{oc}}$ approximately linearly increases from $15 \mathrm{mV}$ to $400 \mathrm{mV}$ 
with rise of the relative humidity from $51 \% \mathrm{RH}$ to $95 \% \mathrm{RH}$. The humidity-sensitivity of $\mathrm{Au} / \mathrm{PS} / \mathrm{Si}$ structure is about $10 \mathrm{mV} /(\% \mathrm{RH})$. The PS/Si structures without Au film on PS surface displayed the low value of $\mathrm{V}_{\text {oc }}$ in humid atmosphere (about of $10 \mathrm{mV}$ at $95 \% \mathrm{RH}$ ). In other words, the presence of the $\mathrm{Au}(\mathrm{Ag}$ or $\mathrm{Cu})$ film on the porous silicon surface is a necessary condition for the generation of electricity in the Au/PS/Si cell in humid atmosphere.

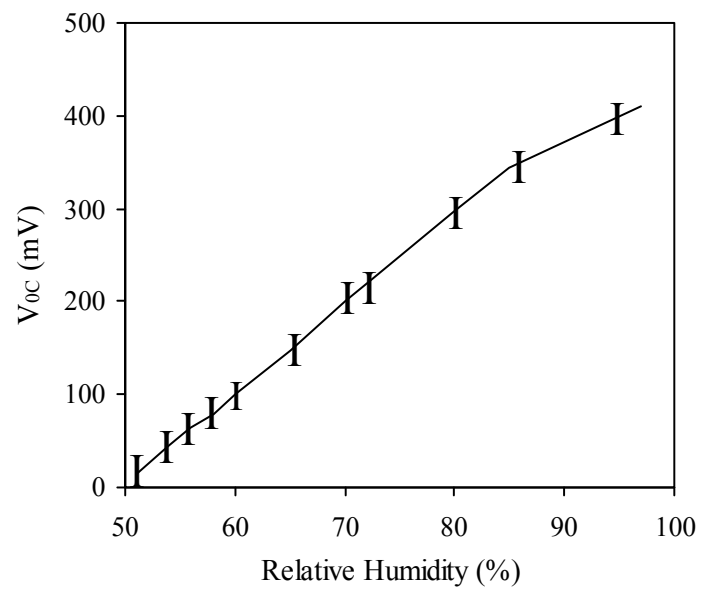

Fig. 9. The open-circuit voltage - RH dependence for Au/PS/Si structure (300 K).

The mechanism of the generation of the electricity in the metal/PS/Si. We suggest that in $\mathrm{Au} / \mathrm{PS} / \mathrm{Si}$ cell, similar to Proton Exchange Membrane (PEM) fuel cell, the Au film and PS layer play the role of the catalytic anode and electrolyte, respectively. The interface region between the porous and crystalline silicon (PS/Si), which is very imperfect and stressed, plays the role of the cathode. Electrons and protons formed in Au catalyst film (anode) after hydrogen splitting (Anode: $\mathrm{H}_{2} \rightarrow 2 \mathrm{H}^{+}+2 e^{-}$), pass through the external circuit and along the pore surfaces of PS layer (electrolyte), respectively and reach the cathode (PS/Si interface) region. Water molecules and oxygen from air can easily penetrate into the PS/Si interface due to the imperfections in this area. Here the hydrogen is recombined and reacts with oxygen to produce water molecules (Cathode: $2 \mathrm{H}^{+}+2 e^{-}+1 / 2 \mathrm{O}_{2} \rightarrow \mathrm{H}_{2} \mathrm{O}$ ).

The hydrogen-containing gas - voltaic effect, i.e., the generation of the open-circuit voltage was also observed for the Au/PS/PS structure in $\mathrm{H}_{2} \mathrm{~S}$ gas atmosphere (Fig. 10 ) (Dzhafarov et al., 2008). Chemical reactions generation of electricity taking place for the case of the $\mathrm{Au} / \mathrm{PS} / \mathrm{Si}$ cell in the $\mathrm{H}_{2} \mathrm{~S}$ gas+air atmosphere will be considered in the late. The sensitivity of the $\mathrm{Au} / \mathrm{PS}$ cell to $\mathrm{H}_{2} \mathrm{~S}$ gas was about $1.8 \mathrm{mV} / \mathrm{ppm}$.

This phenomenon is reversible, i.e., for $\mathrm{Au} / \mathrm{PS} / \mathrm{Si}$ structures, inserting and removing the structure from the gas is accompanied by the response and recovery of $\mathrm{V}_{\mathrm{oc}}$, respectively. Fig. 11 shows the response-recovery behavior of the open-circuit voltage of the $\mathrm{Au} / \mathrm{PS} / \mathrm{Si}$ cell after successive cycles of placing the cell in a $\mathrm{H}_{2} \mathrm{~S}$ atmosphere (45 ppm). It can be seen that the response time is about $60 \mathrm{~s}$. Sensitivity of $\mathrm{Au} / \mathrm{PS} / \mathrm{Si}$ structure to $\mathrm{H}_{2} \mathrm{~S}$ gas (45 ppm) defined from the relation

$$
\mathrm{S}=\left\{\mathrm{V}_{\mathrm{oc}}(\text { gas })-\mathrm{V}_{\mathrm{oc}}(0)\right\} / \mathrm{V}_{\mathrm{oc}}(0)
$$


is equal 16.5. Here $\mathrm{V}_{\text {oc }}$ (gas) and $\mathrm{V}_{\mathrm{oc}}(0)$ are the open-circuit voltage for concentration of $\mathrm{H}_{2} \mathrm{~S}$ gas $45 \mathrm{ppm}$ and 0 , respectively (Fig. 10).

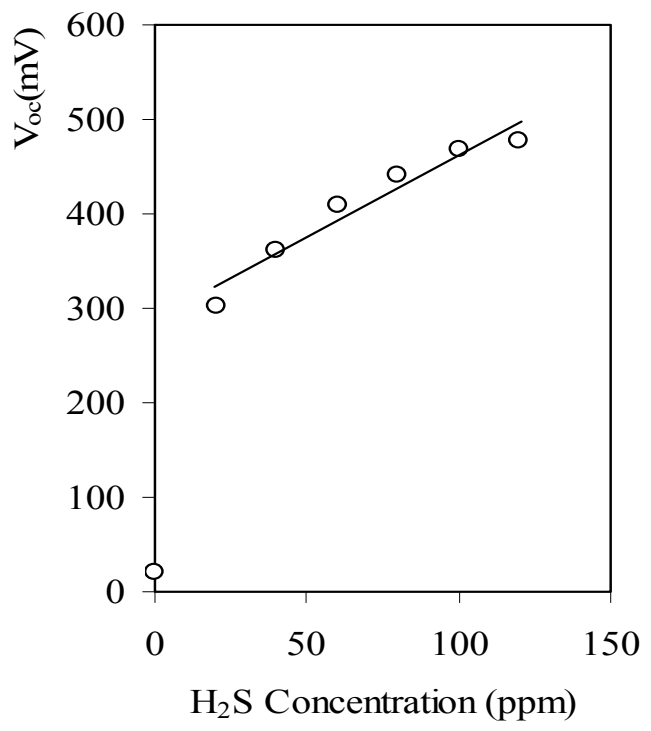

Fig. 10. Voltage generated by Au/PS/Si sensor as a function of the $\mathrm{H}_{2} \mathrm{~S}$ gas concentration.

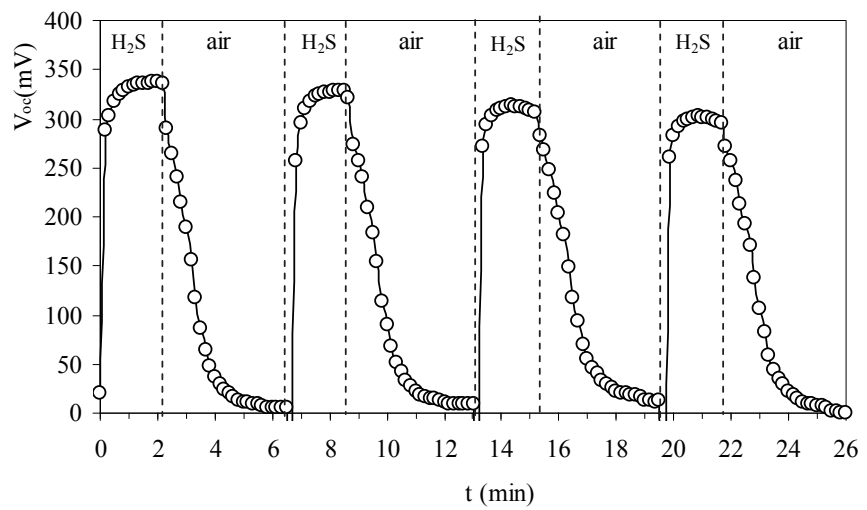

Fig. 11. Voltage response of the Au/PS/Si sensor exposed to $\mathrm{H}_{2} \mathrm{~S}$ gas (45 ppm).

To overall, the voltage generation mechanism in $\mathrm{Au} / \mathrm{PS} / \mathrm{Si}$ structure at $\mathrm{H}_{2} \mathrm{~S}$ atmosphere is similar with the above-described mechanism for humid ambient.

Fig. 12 illustrates the dependence of the open-circuit voltage generated in Au/PS structures on the CO concentration at 45 and 58\% RH (Dzhafarov et al., 2008). An almost linear increase of $\mathrm{V}_{\mathrm{oc}}$ is observed with increasing $\mathrm{CO}$ concentration. $\mathrm{V}_{\mathrm{oc}}$ also increases with rising $\mathrm{RH}$. The increase of voltage at higher humidity observed in Fig. 12 can be related to the 
influence of the increased concentration of water molecules in air. The voltage generated (about $30 \mathrm{mV}$ ), at a zero concentration of $\mathrm{CO}$ gas is related to the humidity of air.

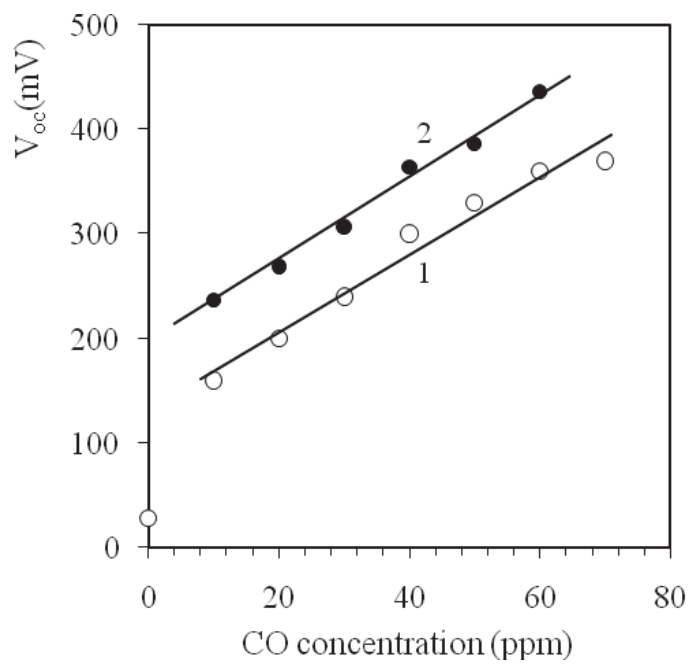

Fig. 12. Voltage generated by Au/PS/Si sensor as a function of the $\mathrm{CO}$ gas concentration in (1) $45 \%$ RH and (2) $58 \%$ RH.

Concerning the operating principle of the $\mathrm{Au} / \mathrm{PS} / \mathrm{Si}$ sensor to detect the $\mathrm{CO}$ molecules, one can suppose that at the first stage, the water molecules from the humid air in the presence of the $\mathrm{Au}$ catalyst interact with the $\mathrm{CO}$, resulting in the formation of hydrogen, according to the electrode reaction (Kohl, 2001)

$$
\begin{gathered}
\mathrm{CO}+\mathrm{H}_{2} \mathrm{O} \rightarrow \mathrm{CO}_{2}+\mathrm{H}_{2} \\
\mathrm{H}_{2} \rightarrow 2 \mathrm{H}^{+}+2 \mathrm{e}^{-} .
\end{gathered}
$$

After the reaction described by eq. (23), the formation of electricity proceeds in accordance with eq. (24). Note that in spite of the absence of hydrogen in the $\mathrm{CO}$ gas, this gas is, nevertheless, hydrogen-producing, as shown by equations (23) and (24).

Thus, the above results, i.e., the voltage generation in the Au/PS/Si Schottky-type structures in a humid, $\mathrm{CO}$, or $\mathrm{H}_{2} \mathrm{~S}$ atmosphere indicate both the fuel cell and gas sensor functionalities of these structures.

The effect of the voltage generation was discovered upon dipping the $\mathrm{Au}(\mathrm{Ag}, \mathrm{Cu}) / \mathrm{PS} / \mathrm{Si}$ structures into different hydrogen-containing solutions ( $\mathrm{KOH}$ (potassium hydroxide), $\mathrm{CH}_{3} \mathrm{CH}_{2} \mathrm{OH}$ (ethanol), $\mathrm{CH}_{3} \mathrm{OH}$ (methanol), $\mathrm{C}_{6} \mathrm{H}_{12} \mathrm{O}_{6}$ (glucose), $\mathrm{H}_{3} \mathrm{BO}_{3}$ (boric acid), $\mathrm{C}_{5} \mathrm{H}_{12}$ $\mathrm{C}_{16} \mathrm{H}_{34}$ (benzine), $\mathrm{NaBH}_{4}$ (sodium borohydride), Black sea-water etc.) (Dzhafarov et al., 2004).

Hydrogen as a source of clean energy has a number of attractive advantages, such as high energy density, nontoxic reaction products and abundant natural resources. However, the application of hydrogen for power sources has been greatly restrained due to the lack of safe and convenient generation and storage methods. Hydrogen can be stored in high pressure tanks or liquefied $\mathrm{H}_{2}$, or by adsorption on activated carbon, carbon nanotubes or in 
hydrogen-storing alloy (Momirlan \& Veziroglu, 2002). Among hydrogen-storing materials, sodium borohydride $\left(\mathrm{NaBH}_{4}\right)$ due to the high hydrogen content (about of $10 \%$ wt or 100 $\mathrm{kg} / \mathrm{m}^{3}$ ) is suggested as new fuel media supplying hydrogen at normal temperatures. The catalytic hydrolysis of sodium borohydride proceeds as

$$
\mathrm{NaBH}_{4}+2 \mathrm{H}_{2} \mathrm{O} \rightarrow \mathrm{NaBO}_{2}+4 \mathrm{H}_{2}
$$

As result of this reaction, each mole $\mathrm{NaBH}_{4}$ can generate 4 moles of hydrogen (8 protons) gas. This is a very effective system, since we are getting hydrogen out of the water as well. We get eight hydrogen atoms (four molecules) from just four atoms of hydrogen in the $\mathrm{NaBH}_{4}$. The hydrogen is formed right there on the anode, and is thus immediately used by the fuel cells. $\mathrm{NaBH}_{4}$ is a nonreversible chemical hydride for the one-time hydrolysis generation of $\mathrm{H}_{2}$. It is shown that $\mathrm{NaBO}_{2}$ byproduct of reaction (20) can be recycle back to $\mathrm{NaBH}_{4}$ using coke or membrane (Kojima \& Haga, 2003).

The effect, similar to humidity-voltaic effect (Dzhafarov et al., 2004)], i.e. the generation a voltage between the contacts to $\mathrm{Au}$ film and $\mathrm{Si}$ under humidity exposition, was also discovered on dipping of $\mathrm{Au} / \mathrm{PS} / \mathrm{Si}$ structure into $\mathrm{NaBH}_{4}$ solution (Dzhafarov et al., 2010). The fuel reactions on anode $(\mathrm{Au})$ surface immersed in $\mathrm{NaBH}_{4}$ fuel and on cathode side (Si) stayed in air is as follows:

$$
\begin{aligned}
& \text { Anode: } \mathrm{NaBH}_{4}+2 \mathrm{H}_{2} \mathrm{O} \rightarrow \mathrm{NaBO}_{2}+8 \mathrm{H}^{+}+8 \mathrm{e}^{-} \\
& \text {Cathode: } 8 \mathrm{H}^{+}+8 \mathrm{e}+2 \mathrm{O}_{2} \rightarrow 4 \mathrm{H}_{2} \mathrm{O}
\end{aligned}
$$

The dependence of the $\mathrm{NaBH}_{4}: \mathrm{H}_{2} \mathrm{O}$ solution conductivity on $\mathrm{NaBH}_{4}$ content measured by using "3200 Conductivity Instrument" (YSI) is presented in Fig. 13. As seen from this figure, the conductivity increases with increasing $\mathrm{NaBH}_{4}$ content. This effect can be caused by hydrogen (proton) production from $\mathrm{NaBH}_{4}$ in water (see eq. (27)).

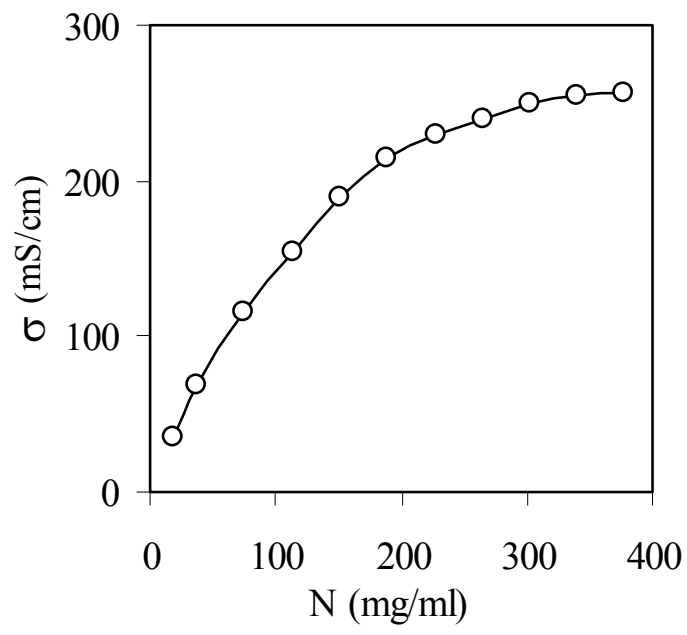

Fig. 13. Conductivity of $\mathrm{NaBH}_{4}: \mathrm{H}_{2} \mathrm{O}$ solution vs. $\mathrm{NaBH}_{4}$ content. 
Fig. 14 illustrates the open-circuit voltage arising in Au/PS/PS structure dependent on the concentration of $\mathrm{NaBH}_{4}$ solution (N) (Dzhafarov et al., 2005; 2010). It is seen that the $\mathrm{V}_{\mathrm{oc}}-\mathrm{N}$ dependence seems to be a curve with a maximum $\left(\mathrm{V}_{\mathrm{oc}}=550 \mathrm{mV}\right)$ at $\mathrm{N}=30 \mathrm{mg} / \mathrm{ml}$. In the range of concentration of $\mathrm{NaBH}_{4}$ solution up to $30 \mathrm{mg} / \mathrm{ml}$ gradient of curve $\left(\mathrm{dV}_{\mathrm{oc}} / \mathrm{dN}\right)$ is large (about $13 \mathrm{mV} . \mathrm{ml} / \mathrm{mg}$ ), i.e. voltage generated in $\mathrm{Au} / \mathrm{PS} / \mathrm{Si}$ structure is very sensitive to $\mathrm{NaBH}_{4}$ concentration. The Au/PS/Si structure on dipping into $\mathrm{NaBH}_{4}$ solution also exhibited the short-circuit current (about of $2.5 \mathrm{~mA} / \mathrm{cm}^{2}$ ). $\mathrm{pH}$ measuring of $\mathrm{NaBH}_{4}$ solution showed that with increase of concentration of $\mathrm{NaBH}_{4}$ from 10 to $30 \mathrm{mg} / \mathrm{ml}, \mathrm{pH}$ of the solution increases from 9.3 to 9.5, i.e. increase of $\mathrm{pH}$ of $\mathrm{NaBH}_{4}$ solution results in increase of voltage generated in the cell (Fig. 14). It should be noted that, as opposed to Au/PS/Si structure, in PS/Si structure (without the Au film) the marked generation of electricity on dipping it in $\mathrm{NaBH}_{4}$ solution was not observed.

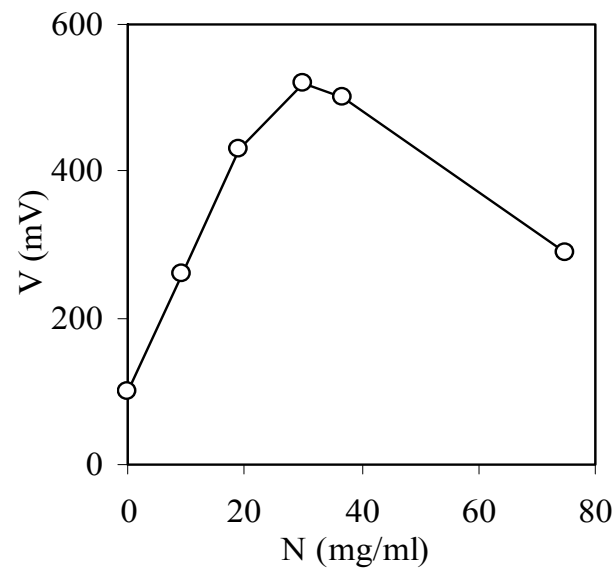

Fig. 14. The voltage generation in $\mathrm{Au} / \mathrm{PS} / \mathrm{Si}$ cell as a function of $\mathrm{NaBH}_{4}$ contains in $\mathrm{NaBH}_{4}: \mathrm{H}_{2} \mathrm{O}$.

The $\mathrm{V}_{\mathrm{oc}}-\mathrm{N}$ dependence observed in Fig. 14 can be explained by two concurrent phenomena. The increase of $\mathrm{NaBH}_{4}$ concentration, for the relative low contents of $\mathrm{NaBH}_{4}(\mathrm{~N}<30 \mathrm{mg} / \mathrm{ml})$, is accompanied by increasing of proton concentration (up to $2 \times 10^{11} \mathrm{~cm}^{-3}$ ) and this results in rising of voltage. We assume that at large content of $\mathrm{NaBH}_{4}(\mathrm{~N}>30 \mathrm{mg} / \mathrm{ml})$, products of reaction (26) precipitate in pores of $\mathrm{Au}$ and porous silicon and thereby hindering penetration of protons to interface. Non-observation of the electricity generation in PS/Si structure (without Au film) can be explained by absence of the catalyst Au film stimulating splitting of $\mathrm{NaBH}_{4}$ molecules. On other hand, at large contents of $\mathrm{NaBH}_{4}(\mathrm{~N}>30 \mathrm{mg} / \mathrm{ml})$, products of reaction (26) precipitate in pores of $\mathrm{Au}$ and porous silicon and thereby hindering penetration of protons to interface. Thus, Schottky-type Au/PS/Si structures sunk in $\mathrm{NaBH}_{4}$ and other hydrogen-containing solutions generate a voltage up to $550 \mathrm{mV}$. These data indicate on availability of using Au/PS/Si structures as hydrogen cells.

The use of $\mathrm{Au}$ /Porous silicon/ Silicon-Schottky type structure as a direct hydrogen sulphide fuel cell was also demonstrated in (Dzhafarov \& Aydin Yuksel, 2011). The porous silicon filled with hydrochloric acid was developed as a proton conduction membrane. The $\mathrm{Au} / \mathrm{PS} / \mathrm{Si}$ cells were fabricated by first creating the porous silicon layer in single-crystalline 
Si using the anodic etching under illumination and then deposition Au catalyst layer onto the porous silicon. The performance of the fuel cell was measured at room temperature by supplying hydrogen sulphide solution and the Black sea-water. Current-voltage characteristics of Au/PS/Si cell at normal air ambient (300 K, 40\%RH), distilled water and $\mathrm{H}_{2} \mathrm{~S}+\mathrm{H}_{2} \mathrm{O}$ solution were shown in Fig. 15. The hydrogen sulphide-stimulated generation of the open-circuit voltage (up to $400 \mathrm{mV}$ ) and the short-circuit current (up to $1 \mathrm{~mA}$ ) was observed for the I-V characteristics of $\mathrm{Au} / \mathrm{PS} / \mathrm{Si}$ cells sunk in $\mathrm{H}_{2} \mathrm{~S}$-containing solution (Fig.15, curve 3), whereas value of $\mathrm{V}_{\mathrm{oc}}$ generated in the distilled water (without $\mathrm{H}_{2} \mathrm{~S}$ ) is markedly lower (about $120 \mathrm{mV}$ ) (Fig.15, curve 2). It should be noted that such effect of electricity formation was not observed in the PS/Si structures lacking the Au film.

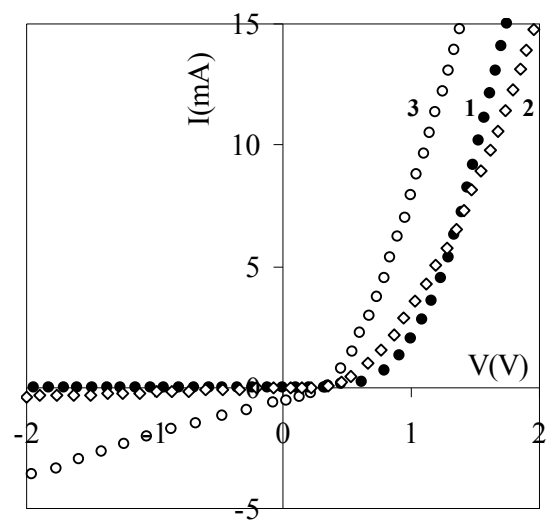

Fig. 15. The current-voltage characteristics of $\mathrm{Au} / \mathrm{PS} / \mathrm{Si}$ structure in (1) air (300K, $40 \% \mathrm{RH})$, (2) distilled water and (3) $\mathrm{H}_{2} \mathrm{~S}+\mathrm{H}_{2} \mathrm{O}$ solution ( $\left.80 \mathrm{mM}\right)$.

The open-circuit voltage generation for the Au/PS/Si cell in $\mathrm{H}_{2} \mathrm{~S}+\mathrm{dH}_{2} \mathrm{O}$ solution at different concentration of $\mathrm{H}_{2} \mathrm{~S}$ is shown in Fig.16.

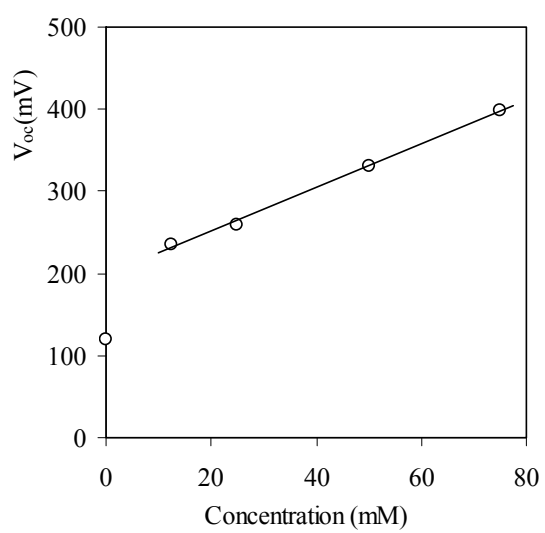

Fig. 16. The voltage generation in Au/PS/Si cell as a function of $\mathrm{H}_{2} \mathrm{~S}$ concentration in distilled water. 
Almost linear increase of voltage (from 230 to $400 \mathrm{mV}$ ) is observed with increasing the $\mathrm{H}_{2} \mathrm{~S}$ concentration from 17 to $75 \mathrm{mM}$. Value of $\mathrm{V}_{\text {oc }}$ in pure water $(120 \mathrm{mV})$ is markedly lower than that in hydrogen sulphide-containing solution (Dzhafarov \& Aydin Yuksel, 2011).

Fig. 17 shows the power output-current density curves of Au/PS/Si cell in $\mathrm{H}_{2} \mathrm{~S}+\mathrm{H}_{2} \mathrm{O}$ solution. Results were gained at room temperature with 12, 23, 50 and $80 \mathrm{mM}$ hydrogen sulphide. From the polarization curves we found that maximum of the power density of the single direct hydrogen sulphide cell increases with concentration of $\mathrm{H}_{2} \mathrm{~S}$ and reaches 30 $\mathrm{W} / \mathrm{m}^{2}$ at $80 \mathrm{mM}$. Such increasing the maximum of the power density with $\mathrm{H}_{2} \mathrm{~S}$ concentration can be caused by increasing of concentration of protons forming in $\mathrm{Au}$ catalyst and diffusing into porous silicon layer.

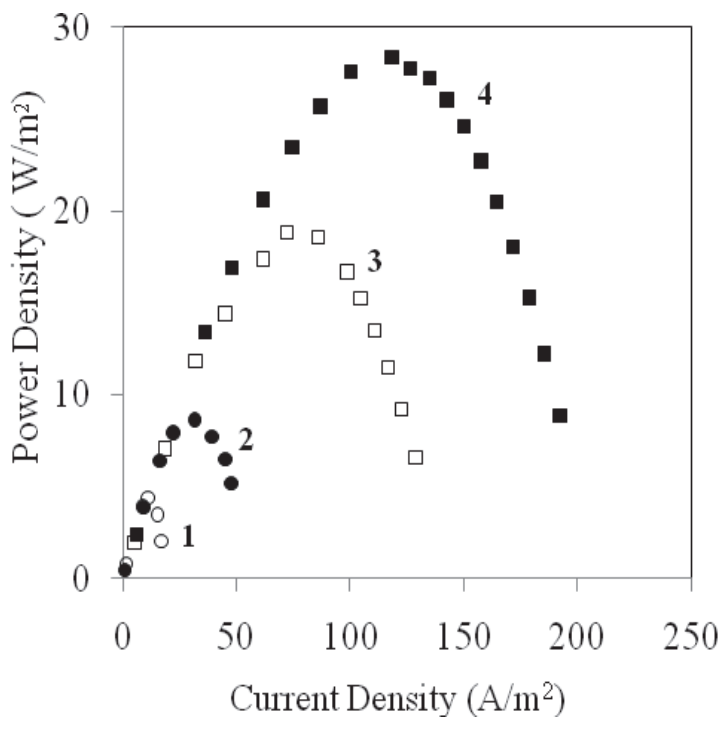

Fig. 17. The power density - current density characteristics of $\mathrm{Au} / \mathrm{PS} / \mathrm{Si}$ cell in $\mathrm{H}_{2} \mathrm{~S}+\mathrm{dH}_{2} \mathrm{O}$ solution of (1) $12 \mathrm{mM}$, (2) $23 \mathrm{mM}$, (3) $50 \mathrm{mM}$ and (4) $80 \mathrm{mM}$ (300 K).

It is known that the Black sea-water contains significant concentration of hydrogen sulphide (about $0.05-1.50 \mathrm{mg} / \mathrm{ml}$ depending on deep water), therefore we made attempt to use the Black sea-water as fuel for Au/PS/Si cells. Indeed, for the Au/PS/Si cell sunk in the Black sea-water, as in case it dipping into $\mathrm{H}_{2} \mathrm{~S}+\mathrm{H}_{2} \mathrm{O}$ solution generation of electricity up to $0.4 \mathrm{~V}$ was observed. It is be noted that successive placing in and removal of the Au/PS/Si cell from $\mathrm{H}_{2} \mathrm{~S}$-containing solution is accompanied by the response and recovery of the value of $\mathrm{V}_{\text {oc }}$ with response time about $40-60 \mathrm{~s}$.

The mechanism of the generation of the electricity in the metal/PS/Si cells under hydrogencontaining ambient has already been proposed (Dzhafarov et al., 2008). We suggest that in $\mathrm{Au} / \mathrm{PS} / \mathrm{Si}$ cell, similar to direct ethanol fuel cell [39], the Au film and PS layer filled with hydrochloric acid play the role of the catalytic anode and electrolyte respectively. In the case of $\mathrm{Au} / \mathrm{PS} / \mathrm{Si}$ direct hydrogen sulphide fuel cell, $\mathrm{H}_{2} \mathrm{~S}+$ water solution as fuel is supplied at the $\mathrm{Au}$ anode and porous silicon layer acts as the electrolyte. The following reactions take place in the presence of a catalyst (Basu, 2007; Hoogers, 2003) 
At the anode: $\quad \mathrm{H}_{2} \mathrm{~S}+2 \mathrm{H}_{2} \mathrm{O} \rightarrow \mathrm{SO}_{2}+6 \mathrm{H}^{+}+6 \mathrm{e}^{-}$

At the cathode: $\quad 6 \mathrm{H}^{+}+6 \mathrm{e}^{-}+3 / 2 \mathrm{O}_{2} \rightarrow 3 \mathrm{H}_{2} \mathrm{O}$

The overall reaction can be expressed as

$$
2 \mathrm{H}_{2} \mathrm{~S}+3 \mathrm{O}_{2} \rightarrow 2 \mathrm{SO}_{2}+2 \mathrm{H}_{2} \mathrm{O}
$$

Electrons and protons formed in the Au catalyst film after hydrogen splitting $\left(\mathrm{H}_{2} \rightarrow 2 \mathrm{H}^{+}+\right.$ $2 \mathrm{e}-)$, pass through the external circuit and PS layer, respectively and reach the cathode (PS/Si interface) region. The oxygen from air can easily penetrate into the PS/Si interface due to the imperfections in this area. Here the hydrogen is recombined and reacts with oxygen to produce water molecules. Generation of the electricity in pure water without $\mathrm{H}_{2} \mathrm{~S}$ (Fig.16) can be related with water splitting in part on the Au catalyst layer $\left(2 \mathrm{H}_{2} \mathrm{O} \rightarrow 2 \mathrm{H}_{2}+\right.$ $\mathrm{O}_{2}$ and $\left.\mathrm{H}_{2} \rightarrow 2 \mathrm{H}^{+}+2 \mathrm{e}^{-}\right)$.

Stability of operation for Au/PS/Si cells as a function of storage time in the presence of the hydrogen sulphide solution $(80 \mathrm{mM})$ was observed for about $100 \mathrm{~h}$. More long-time tests of operation stability of the cell are currently under investigation. Moreover, nature of molecules responsible for generation of electricity on placing of the Au/PS/Si cell in the Black sea-water is yet remained non-clear.

These results allow supposing that the Au/PS/Si structures can be used as the hydrogen sulphide miniature fuel cells. In addition to this, the nearly linear dependence the open circuit voltage generated in $\mathrm{Au} / \mathrm{PS} / \mathrm{Si}$ cell in dependence on concentration of $\mathrm{H}_{2} \mathrm{~S}$ in hydrogen sulphide containing solution (Fig. 16) permits of using such structures as hydrogen sulphide sensors with sensitivity about $2.5 \mathrm{mV} / \mathrm{mM}$.

The similar effect of voltage generation was also observed during dipping of $\mathrm{Ag} / \mathrm{PS}$ structures in other hydrogen-containing solutions (the distilled water, fresh water, Black sea-water, ethanol and methanol) (Table 2) (Dzhafarov et al., 2008).

\begin{tabular}{|c|c|c|}
\hline Ambient & Conductivity of solution $(\mathrm{mS} / \mathrm{cm})$ & $\mathrm{V}(\mathrm{mV})$ \\
\hline Humid (95\% RH) & & 430 \\
\hline Distilled water & 0.08 & 505 \\
\hline Fresh-water & 0.47 & 514 \\
\hline Black sea-water & 48.4 & 559 \\
\hline Ethanol & 0.0095 & 254 \\
\hline Methanol & 0.047 & 380 \\
\hline
\end{tabular}

Table 2. Data on $\mathrm{V}_{\text {oc }}$ generated in Ag/PS/Si cells in humid and in the hydrogen-containing solutions

Largest value of voltage, generated in Black sea-water for the cell can be caused by contribution of the hydrogen sulphide molecules in sea-water. As can be seen from Table 2, the correlation between changes of the $\mathrm{V}_{\mathrm{oc}}$ and $\mathrm{J}_{\mathrm{sc}}$ parameters of $\mathrm{Ag} / \mathrm{PS} / \mathrm{Si}$ cells and the conductivity of hydrogen-containing solution is observed. Such correlation can be tentatively explained by an increase of concentration of the charge particles, deposited on the pore surfaces with increase of conductivity of solutions. 


\section{Conclusion}

Thus, the Metal $(\mathrm{Au}, \mathrm{Ag}$ or $\mathrm{Cu}) /$ Porous silicon/Silicon structures placed in hydrogencontaining gas or liquid ambient generate voltage $(400-550 \mathrm{mV})$ and maximum power density of $30 \mathrm{~W} / \mathrm{m}^{2}$. These results demonstrate the feasibility of development of low-cost small porous silicon-based direct hydrogen fuel cells for portable electronics and medical applications. Moreover, the $\mathrm{Au} /$ Porous silicon structures can be used as hydrogen-sensitive sensors.

\section{References}

Abdullaev, G.B. \&. Dzhafarov T.D. (1987). Atomic Diffusion in Semiconductor Structures, Harwood Academic Press, New York, ISBN 3-7186-0413-2

Aravamudhan, S., Rahman, A. \& Bhansali, Sh. (2005). Porous Silicon Based Orientation Independent Self-priming Micro Direct Ethanol Fuel Cell. Sensors and Actuators, Vol.A123-124, (2005), pp. 497-499, ISSN 0924-4247

Basu, S. (2007). Recent Trends in Fuel Cell Science and Technology, Springer, New York, ISBN 978-0-387-355537-5

Beale, M.I.J, Benjamin, J.D., Uren, M.J., Chew, N.G. \& Cullis, A.G. (1985). An Experimental and Theoretical Study of the Formation and Microstructure of Porous Silicon. Journal of Crystal Growth, Vol. 73, (1985), pp. 622- 636, ISSN 0022-0248

Bisi, O., Ossicini, S. \& Pavesi, L. (2000). Porous Silicon: a Quantum Sponge Structure for Silicon Based Optoelectronic. Surface Science Reports, Vol.38, No.1-126, (April 2000), pp.1-129, ISSN 0167-5729

Bove, R. \& Ubertini, S. (eds.). (2008). Modeling Solid Oxide Fuel Cell, Springer, Berlin, ISNB13: 978-1-4020-6994-9, e-ISBN-13: 978-1-4020-6995-6

Bunker, C.E., Simmons, K.J. \& Rollins, H.W. (1998). Steady-state and Time-resolved Fluorescence Spectroscopic Probing of Microstructures and Properties of Perfluorinated Polyelectrolyte Membranes. Journal of Electroanalytical Chemistry, Vol. 459 (1998) pp.15-28, ISSN 1572-6657

Canham, L.T. (Ed.) (1997). Properties of Porous Silicon, IEE-Inspec, London, 0-86341-555-5

Chu, K., Shanon, M.A. \& Masel, R.I. (2007). Porous Silicon Fuel Cell for Micro Power Generation. Journal of Micromechanics and Microengineering, Vol.17, (2007), pp. S243S247, ISSN 0960-1317

Cook L.M. (1990). Chemical Processes in Glass Polishing. Journal of Non-crystalline Solids, Vol.120, No.4, (1990), pp.152-171

Crawley, G. (2007). Direct Methanol Fuel Cells (DMFC). Fuel Cell Today (Informing for Fuel Cell Industry), (August 2007)., pp.1-13

D'Arrigo, G. D., Spinella, C., Arena, G. \& Lorenti, S. (2003). Fabrication of Miniaturized Sibased Electrolytic Membranes. Materials Science and Engineering C. Vol. 23. No.1-2, (January 2003), pp.13-18, ISSN 0928-4931

Dzhafarov, T.D. \& Can, B. (2000). The Diffusion Distribution of Hydrogen and Oxygen in Porous Silicon Films. Journal of Materials Science Letters, Vol.19, (2000), pp. 287-289, ISSN 0261-8028

Dzhafarov, T.D. \& Can, B. (2000). Humidity-voltaic Characteristics of Ag-PS-Si Structures. Journal of. Materials Science Letters, Vol.19, (2000), pp.2193-2195, ISSN 0261-8028

Dzhafarov, T.D., Can Omur, B., Oruc, C. \& Allahverdiev, Z.A. (2002). Hydrogen-sensing Characteristics of Cu-PS-Si Structures. Journal of Physics D: Applied Physics, Vol. 35, (2002), pp.3122-3126, ISSN 022-3727 
Dzhafarov, T.D., Oruc, C. \& Aydin, S. (2004). Humidity-voltaic Characteristics of Au-Porous Silicon interfaces. Journal of Physics D: Applied Physics, Vol. 37, (2004), pp. 404-408, ISSN 022-3727

Dzhafarov, T.D., Oruc Lus, C. \& Aydin, S. (2005). Metal/Porous Silicon Schottky-type Hydrogen Fuel Cells. Proc. of Ninth Grove Fuel Cell Symposium, pp. 17-19, London, (4-6 October 2005)

Dzhafarov, T.D., Aydin, S. \& Oruc Lus, C. (2007). Effect of Humidity on Optical and Electrical Properties of Free-standing Porous Silicon Films. Fizika, Vol.8, No.5, (2007), pp. 17-20, ISSN 1028-8546

Dzhafarov, T.D., Aydin Yuksel, S. \& Oruc Lus, C. (2008). Porous Silicon-based Gas Sensors and Miniature Hydrogen Cells. Japan Journal of Applied Physics, Vol. 47, No. 10, (2008), pp. 8204-8207, ISSN 0021-4922

Dzhafarov, T.D., Aydin, S. \& Oren, D. (2008). Effect of Diffusion of 1 Group Metal on Characteristics of Metal/Porous Silicon Sensors. Solid State Phenomena, Vol.131-133, (2008), pp. 189-194, ISSN 1012-0394

Dzhafarov, T.D. \& Aydin, S. (2009). Nano-porous Silicon for Gas Sensors and Fuel Cell Applications. Journal of Gafqaz University, No. 25, (2009), pp. 20-35, ISSN 1302-6763

Dzhafarov, T.D. \& Aydin, S. (2010). Diffusion of Hydrogen in Porous Silicon-based Sensors. Journal of Porous Media, Vol.13, No.2, (2010), pp. 97-102, ISSN 1091-028X

Dzhafarov, T.D., Oruc Lus, C., Aydin Yuksel, S., Caliskan, M. \& Yesilkaya, S.S. (2010). $\mathrm{Au}$ /Porous Sillicon-based Sodium Borohydride Fuel Cells. International Journal of Energy Research, Vol.34, No.15, (2010), pp. 1386-1392, ISSN 0363-907X

Dzhafarov, T.D. \& Aydin Yuksel, S. (2011). Silicon-based Direct Hydrogen Sulphide Fuel Cells. Journal of Nanoscience and Nanotechnology, Vol.11, No.3, (2011), pp. 843-848, ISSN 1550-7033

Feng Z.C. \& Tsu, R. (1994). Porous Silicon, World Scientific, ISBN 981-02-1634-3, Singapore

Gold, S., Chu, K., Lu, C., Shanon, M.A. \& Masel, R.I. (2004). Acid Loaded Porous Silicon as a Proton Exchange Membrane for Micro Fuel Cells. Journal of Power Sources, Vol.135, (2004), pp.198-203, ISSN 0378-7753

Gyoko, N. \& Naohiro I. (2005). Porous Silicon as a Proton Exchange Membrane for Micro Fuel Cells. Electrochemistry, Vol. 73, No. 11, (2005), pp. 939-943, ISSN 0013-4651

Hahn, R., Wagner, S. \& Reicht, H. (2007). Chapter 8. Constraint of PEM Micro Fuel Cells for Portable Electronics, In: Fuel Cell Electronics Packaging, Kuang, K. \& Easter, K., pp. 145-163, Springer, Berlin, ISBN-13: 978-0-387-47323-9, e-ISBN-13: 978-0-387-47324-6.

Hayase, M., Kawase, T. \& Hetsuzawa, T. (2004). Miniature $250 \mu \mathrm{m}$ Thick Cell with Monolithically Fabricated Silicon Electrodes. Electrochemical Solid-State Letters, Vol. 7, (2004), No. 8, pp. A231-234.

Herino, R (1998). Pore Size Distribution in Porous Silicon, In: Canham, L. (Ed.). Properties of Porous Silicon, Inspec, London, pp. 89-98, ISNN 0-86341-555-5

Hockaday, R.G. (2000). Microfuel Cells for Portable Electronics, Manthattan Scientifics, Power, Santiego

Hoffmann, P. (2002). Tomorrow Energy: Fuel Cells and the Prospect for a Cleaner Planet. MIT Press, New York, ISBN-10: 026258221X, ISBN-13: 978-0262582216

Hoogers G. (Ed.). (2003). Fuel Technology Handbook, CRC Press, New York, ISSN 1095-4244

Jung D.H. (2002). Performance Evaluation of a Hybrid Nafion ${ }^{\circledR} /$ Silicon Oxide Membrane for Direct Methanol Fuel Cell. Journal of Power Sources, Vol. 106, (2002), pp.173-177, ISSN 0378-7753 
Kamarudin, S.K., Achmad, F.\& Daud, W.R.W. (2009). Overview on the Application of Direct Methanol Fuel Cell (DMFC) for Portable Electronic Devices. International Journal of Hydrogen Energy, Vol. 34, No. 16, (August 2009), pp. 6902-6916.

Kojima,Y. \& Haga,T. (2003). Recycling Process of Sodium Metaborate to Sodium Borohydride. Journal of Hydrogen Energy, Vol.28, (2003), pp. 989-993, ISSN 0360-3199

Kohl, D. (2001). Function and Application of Gas Sensors. Journal of Physics. D, Vol.34, (2001) pp. R125-R149, ISSN 022-3727

Lee, C., Lee, S., Huang, R. \& Chuang, C. (2007). Application of Porous Silicon on the Gas Diffusion Layer of Micro Fuel Cells. Key Engineering Materials, Vol.364-366, (2007), pp. 849-854

Lysenko, V., Bidault, F. \& Alekseev, S. (2005). Study of Porous Silicon as Hydrogen Reservoirs, Journal of Physical Chemistry B, Vol.109, No. 42, (2005), pp. 1971119718, ISSN 1089-5647

Maynard, H.L. \& Meyers, J.P. (2000). Small Fuel Cells. Proc. of 2-nd Annual Small Fuel Cells and Battery Technologies for Portable Power Applications Int. Symp., New Orleans, 2000

Mench, M.M. (2008). Fuel Cell Engines, Wiley, New York, ISBN 978-0-471-68958-4

Moghaddam, S., Pengwang, E., Masel, R.I. \& Shannon, M.A. (2009). Nanostructured Siliconbased Proton Exchange Membrane for Micro Fuel Cells. Power MEMS, December 14 (2009), pp.116-119

Momirlan, M. \& Veziroglu, T.N. (2002). Current Status of Hydrogen Energy. Renewable and Substainable Energy Reviews, Vol. 6, No. 1-2, (2002), pp. 141-179, ISSN 1364-0321

Ohashi, M., Guo, Z., Wang, N. \& Tseng, K.H. (2010). Small DMFC for Portable Applications, Fujika Technical Review, Vol. 1, (2010), pp.44-46

O'Hayre, R., Cha, S.W., Corella,,W. \& Prinz, F.B. (2009). Fuel Cell Fundamentals, Wiley, New Jersey, ISBN-13: 978-0-471-74148-0, ISBN-10: 0471-74148-5

Pichonat,T. \& Gauthier-Manuel,B. (2005). Development of Porous Silicon-based Miniature Fuel Cells., Journal of Micromechanical and Microengineering, Vol.15, No. 9, (2005), pp.179-184, ISSN 0960-1317

Song, J.H. \& Sailor, M.J. (1999). Chemical Modification of Crystalline Porous Silicon Surfaces. Comments on Inorganic Chemistry, Vol.21, No. 1-3, (1999), pp. 69-84, ISSN 0260-3594

Starkov, V.V., Redskin, A.N. Dubonos, S.V. (2006). Carbon Nanofibers in a Gradient-Porous Silicon Structure. Technical Physics Letters, vol. 32, (2006), No. 1, pp. 82-83

Stewart, M.P.\& Buriak J.M. (2000). Chemical and Biological Application of Porous Silicon Technology. Advanced Materials, Vol.12, No. 12, (2000), pp. 859-869, ISSN 0935-9648

US PATENT 5266421-Enhanced membrane-electrode interface, granted 2008-11-30

Varga, A. (2007). Chapter1. Introduction to Fuel Cell Technology, In: Fuel Cell Electronics Packaging, Kuang, K. \& Easter, K., pp. 145-163, Springer, Berlin, ISBN-13: 978-0-38747323-9, e-ISBN-13: 978-0-387-47324-6

Vielstich, W., Gasteiger, H.A. \& Yokoka, H. (eds.) (2009). Handbook of Fuel Cells: Advances in Electro-catalysts, Materials, Diagnostics and Durability. Vol. 5 \& 6. Wiley, Hoboken, ISSN 978-0-470-74151-1

Vielstich,W.,Lamm,A. \& Gasteiger, H.A. (eds.). (2003). Handbook of Fuel Cells: Fundamentals, Technology, Applications. Vol.1-4, Wiley, New Jersey, ISBN: 978-0-71-49926-8

Yamaguchi, A., Ibe, M., Nair, B.N. \& Nakao, S. (2002). A Pore-filling Electrolyte MembraneElectrode Integrated System for Direct Methanol Fuel Cell Application. Journal of Electrochemical Society, Vol. 149, No. 11, (2002), pp. A1448-1453, ISSN 0013-4651 http://public.itrs.net/, International Roadmap for Semiconductors, executive summary. (2003). Technical report, SIA 


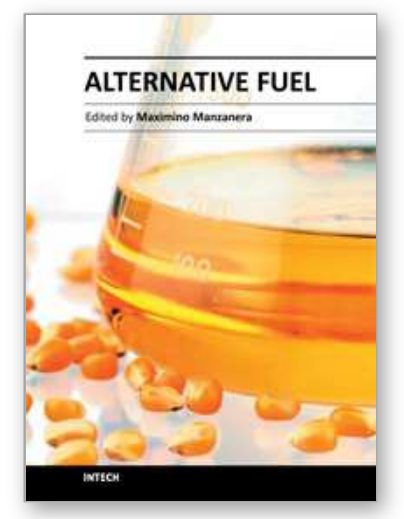

\author{
Alternative Fuel \\ Edited by Dr. Maximino Manzanera
}

ISBN 978-953-307-372-9

Hard cover, 346 pages

Publisher InTech

Published online 09, August, 2011

Published in print edition August, 2011

Renewable energy sources such as biodiesel, bioethanol, biomethane, biomass from wastes or hydrogen are subject of great interest in the current energy scene. These fuels contribute to the reduction of prices and dependence on fossil fuels. In addition, energy sources such as these could partially replace the use of what is considered as the major factor responsible for global warming and the main source of local environmental pollution. For these reasons they are known as alternative fuels. There is an urgent need to find and optimise the use of alternative fuels to provide a net energy gain, to be economically competitive and to be producible in large quantities without compromising food resources.

\title{
How to reference
}

In order to correctly reference this scholarly work, feel free to copy and paste the following:

Tayyar Dzhafarov and Sureyya Aydin Yuksel (2011). Nano-Porous Silicon-Based Mini Hydrogen Fuel Cells, Alternative Fuel, Dr. Maximino Manzanera (Ed.), ISBN: 978-953-307-372-9, InTech, Available from: http://www.intechopen.com/books/alternative-fuel/nano-porous-silicon-based-mini-hydrogen-fuel-cells

\section{INTECH}

open science | open minds

\section{InTech Europe}

University Campus STeP Ri

Slavka Krautzeka 83/A

51000 Rijeka, Croatia

Phone: +385 (51) 770447

Fax: +385 (51) 686166

www.intechopen.com

\section{InTech China}

Unit 405, Office Block, Hotel Equatorial Shanghai

No.65, Yan An Road (West), Shanghai, 200040, China

中国上海市延安西路65号上海国际贵都大饭店办公楼405单元

Phone: +86-21-62489820

Fax: +86-21-62489821 
(C) 2011 The Author(s). Licensee IntechOpen. This chapter is distributed under the terms of the Creative Commons Attribution-NonCommercialShareAlike-3.0 License, which permits use, distribution and reproduction for non-commercial purposes, provided the original is properly cited and derivative works building on this content are distributed under the same license. 